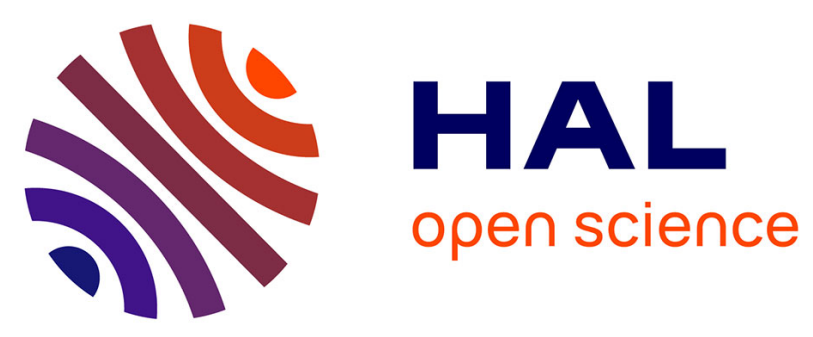

\title{
Evolutionary trajectory of channel planforms in the middle Garonne River (Toulouse, SW France) over a 130-year period: Contribution of mixed multiple factor analysis (MFAmix)
}

Mélodie David, Amaury Labenne, Jean-Michel Carozza, Philippe Valette

\section{To cite this version:}

Mélodie David, Amaury Labenne, Jean-Michel Carozza, Philippe Valette. Evolutionary trajectory of channel planforms in the middle Garonne River (Toulouse, SW France) over a 130-year period: Contribution of mixed multiple factor analysis (MFAmix). Geomorphology, 2016, 258, pp.21 - 39. 10.1016/j.geomorph.2016.01.012 . hal-01447649

\section{HAL Id: hal-01447649 \\ https://hal-univ-tlse2.archives-ouvertes.fr/hal-01447649}

Submitted on 27 Jan 2017

HAL is a multi-disciplinary open access archive for the deposit and dissemination of scientific research documents, whether they are published or not. The documents may come from teaching and research institutions in France or abroad, or from public or private research centers.
L'archive ouverte pluridisciplinaire HAL, est destinée au dépôt et à la diffusion de documents scientifiques de niveau recherche, publiés ou non, émanant des établissements d'enseignement et de recherche français ou étrangers, des laboratoires publics ou privés. 


\section{Evolutionary trajectory of channel planforms in the middle Garonne River (Toulouse, SW}

France) over a 130-year period: Contribution of mixed multiple factor analysis (MFAmix)

Mélodie David $^{a *}$, Amaury Labenne ${ }^{\mathrm{b}, 1}$, Jean-Michel Carozza ${ }^{\mathrm{c}, 2}$, Philippe Valette ${ }^{\mathrm{a}, 3}$

${ }^{a}$ GEODE - UMR 5602 [CNRS/Université Toulouse Jean Jaurès], Maison de la Recherche, 5 allée Antonio Machado, 31058 Toulouse cedex 9, France

${ }^{\mathrm{b}}$ Irstea, Unité ETBX, 50 avenue de Verdun, Gazinet, 33612 Cestas Cedex, France

${ }^{c}$ LIENSS - UMR 7266 [CNRS/Université de la Rochelle], Faculté des lettres, langues, arts et sciences humaines, 1 Parvis Fernand Braudel, 17042 La Rochelle cedex 1, France

* Corresponding author. Tel.: +33 5615036 30; +336 825125 50; E-mail: melodie.david@etu.univtlse2.fr

${ }^{1}$ E-mail: amaury.labenne@irstea.fr

${ }^{2}$ E-mail: jmcarozza@yahoo.fr

${ }^{3}$ E-mail: philippe.valette@univ-tlse2.fr

\section{Abstract}

The purpose of this study is to propose a methodological essay for defining evolutionary trajectories of channel planforms and to examine the channel change in the middle Garonne River (southwest France) over a 130-year period. The study focuses on a reach of $\sim 90 \mathrm{~km}$ situated downstream from the city of Toulouse. A set of four historical maps (1868, 1940s, 1970s, and 2000s) is used to build a geomorphometric diachronic database. Data processing through mixed multiple factor analysis (MFAmix) and hierarchical cluster analysis (HCA) allows distinction between four homogeneous zones within the study reach, depending on their evolutionary trajectories. Channel behavior in the upstream and median zones evolved as of the beginning of the study period (narrowing of the fluvial area, colonization by vegetation, and removal of alluvial bars), likely owing to punctual anthropogenic actions. The downstream zone is characterized by stabilization of the channel and alluvial bar removal over the second half of the twentieth century, coinciding with the campaign undertaken by French local authorities between 1960 and 1984 to protect river banks. The role of 
climate transition between the Little Ice Age (LIA) and the onset of the Global Warming period (GW) is also discussed. Results generally are consistent with the chronology established for most European rivers.

Key words: Garonne River; evolutionary trajectory; channel change; multiple factor analysis (MFA); Little Ice Age (LIA); anthropogenic impact

Abbreviations: GCP (Ground Control Point); GIS (Geographic Information System); GW (Global Warming); HCA (Hierarchical Cluster Analysis); HMB (Historical Meander-Belt); IGN (Institut Géographique National); LIA (Little Ice Age); MFAmix (mixed Multiple Factor Analysis); PCA (Principal Component Analysis); RMS (Root Mean Square).

\section{Introduction}

Since the end of the nineteenth century, significant morphological channel changes have been observed along European rivers (examples of recent studies showing this phenomenon: Ollero, 2010 northern Spain; Zawiejska and Wyzga, 2010 - Polish Carpathians; Kiss and Blanka, 2012 - Hungarian Carpathians; Radoane et al., 2013 - Romanian Carpathians; Segura-Belträn and Sanchis-lbor, 2013 eastern Spain; Campana et al., 2014 - Italian Alps; Latapie et al., 2014 - Loire River, central France; Provansal et al., 2014 - Rhône River, southeast France; Toone et al., 2014 - Drôme River, southeast France; Arnaud et al., 2015 - Rhine River in France and Germany; Clerici et al., 2015 - Italian northern Apennines; Scorpio et al., 2015 - southern Italy; etc.). The major processes involved, channel incision and narrowing, have several consequences, especially the alteration of ecosystem services caused by loss of habitats (Bravard et al., 1997; MEA, 2005). A fundamental understanding of past channel adjustments of each river reach is now widely recognized when undertaking river management/restoration (e.g., Kondolf and Larson, 1995; Brierley et al., 2008). This provides a coherent set of insights from which to assess the morphological recovery potential of the river and the predisturbance biophysical conditions useful in defining a target reference state (Brierley and Fryirs, 2005; Fryirs et al., 2009). 
Various studies have demonstrated that an intense degradation phase occurred over the last 50 years in most European rivers (e.g., Peiry and Nouguier, 1994; Liébault and Piégay, 2002; Comiti et al., 2011; Ziliani and Surian, 2012; Arnaud et al., 2015; Scorpio et al., 2015) as the result of anthropogenic measures taken after World War II: bank protection, in-stream gravel extraction, and dam construction (Kondolf, 1997; Gregory, 2006; Goudie, 2013). Earlier adjustments observed in several rivers since the end of the nineteenth century have often been interpreted as a consequence on floods and sediment delivery of climate change, i.e., the transition from the Little Ice Age (LIA) to Global Warming (GW) (e.g., Rumsby and Macklin, 1996; Liébault and Piégay, 2002; Arnaud-Fassetta, 2003; Gob et al., 2008; Astrade et al., 2011; Carozza et al., 2012). Moreover, since the 1990s, several Italian rivers have entered into a recovery phase as seen in the widening of their channels (Surian and Rinaldi, 2004; Surian and Cisotto, 2007; Rinaldi et al., 2009; Surian et al., 2009; Comiti et al., 2011; Ziliani and Surian, 2012; Bollati et al., 2014; Scorpio et al., 2015).

The Garonne River (southwestern France) is one of the main rivers in France and flows into the largest estuary in Europe, the Gironde estuary, downstream of the confluence of the Dordogne River. Despite its geographical, hydrological, and geomorphological importance, only a very few investigations have analyzed the history of geomorphologic adjustments in the Garonne fluvial system, compared to rivers of the same order of magnitude (i.e., the Rhône, Rhine, or Loire catchments). Therefore, the comparison of the level of degradation of the Garonne with other European rivers is currently difficult. To date, the so-called Toulouse middle Garonne, extending $90 \mathrm{~km}$ from the city of Toulouse to the Tarn River confluence (Fig. 1), is the most documented reach of the river. Several studies, focused on the second half of the twentieth century, have highlighted a degradation in the hydromorphological dynamics in this reach over the last 50 years: bedload removal, localized channel bedrock incision, reduction of lateral channel adjustments, and riparian wetland disconnection (Beaudelin, 1989; Steiger et al., 1998, 2000; Steiger and Corenblit, 2000). These phenomena have been interpreted as a response to human disturbance in the channel and in the catchment (in-stream gravel extraction, channelization, dam construction, and reforestation). Other studies, focused on more localized parts of the Toulouse middle Garonne (Decamps et al., 1989; Valette and Carozza, 2010; David et al., 2015) or tending to emphasize landscape change and 
ecological issues (Valette and Gazelle, 2000; Muller et al., 2002; Valette, 2002; Valette and Carozza, 2010; Valette et al., 2014), have provided signs of an active-belt narrowing prior to the 1960s. In addition, a bed incision has been documented at several points in the fluvial reach since the early twentieth century (Beaudelin, 1989; Steiger et al., 1998, 2000; Steiger and Corenblit, 2000). Thus, the processes observed since the 1960s likely have roots in a longer evolution, related to former human disturbances and/or a shift in climate, i.e., the LIA to GW transition during the last years of the nineteenth century. However, neither systematic nor quantitative analysis has clearly demonstrated the extent, pattern, rate, and causes of these evolutions. In this study, we propose to help overcome this lack by analyzing the evolutionary trajectory of channel planforms in the Toulouse middle Garonne on a 130 -year timescale and to thus gain a better understanding of the origin, timing, and controls of the current dynamics.

Many authors have examined morphological adjustment of fluvial systems using historical data, especially maps, aerial photographs, or remote sensing (e.g., Patrick et al., 1982; Hickin and Nanson, 1984; Lewin, 1987; Petts, 1989; Erskine, 1992; Marston et al., 1995; Gurnell, 1997; Winterbottom, 2000; Uribelarrea et al., 2003; Wellmeyer et al., 2005; Nicoll and Hickin, 2010; Zawiejska and Wyzga, 2010; Ziliani and Surian, 2012; Segura-Belträn and Sanchis-Ibor, 2013; Toone et al., 2014; Clerici et al., 2015; Scorpio et al., 2015; etc.). In most studies using these types of data, channel change is analyzed through the measure of one or several geomorphological parameters (e.g., channel width, sinuosity, etc.) at regularly spaced intervals along the study reach. The procedure is repeated for each of the available documents, and the evolution is reconstructed through analysis of two types of graph: (i) a line chart of the values evolution along the study reach, in order to highlight homogeneous segments (the search for significant statistical breaks in the series can be an automated procedure; Arnaud, 2012) but can consider only one parameter at time, and (ii) a line chart of the values evolution over the study period in order to decipher adjustment phases. This approach, well established in the literature (e.g., Ziliani and Surian, 2012; Clerici et al., 2015; etc.), allows spatial and temporal morphodynamic variations to be quantitatively investigated. However, the larger the number of parameters needed to characterize the river morphology, the greater the complexity in the analysis of correlations between line charts. 
A common approach to automatic analysis of correlations between parameters consists in performing multivariate analyses. These methods, commonly used in fluvial geomorphology (Clément and Piégay, 2003), are well adapted to highlighting spatial tendencies along a river reach. However, they usually can consider only one document at a time, thus they are rarely used for diachronic morphological analyses. In this paper, we propose a methodological essay that involves using multiple factor analysis (MFA; Escofier and Pagès, 1998) for mixed data (MFAmix; Chavent et al., 2012). The initial step remains identical to the procedure described above: a set of morphological parameters is computed on subreaches of $1 \mathrm{~km}$ in length along the Toulouse middle Garonne, on four historical maps $(1868,1940$ s, 1970s, and 2000s). The MFAmix is then used to provide an automatic analysis of correlations between quantitative and qualitative morphological parameters organized in groups, that correspond to the dates of the different maps. The results of the MFAmix are post-treated by performing hierarchical cluster analysis (HCA). The output is a synthetic typology of the evolutionary trajectories of channel planforms within the study reach over a 130-year period. With this approach it is thus possible to highlight homogeneous zones within a fluvial reach, which, in turn, depend on the historical evolution of the channel behavior.

\section{Study area}

\subsection{General setting}

The Garonne River is a transborder Franco-Spanish river originating in the Pyrenees Mountains (Fig. 1). Despite its reduced total length and mean discharge $\left(647 \mathrm{~km}\right.$ for $\left.617 \mathrm{~m}^{3} . \mathrm{s}^{-1}\right)$, the river forms the largest estuary in Europe (the Gironde) at the confluence with the Dordogne River, $75 \mathrm{~km}$ upstream of the Atlantic Ocean. Given the surface of its catchment $\left(56,000 \mathrm{~km}^{2}\right)$ and the length of its channel within French territory $(522 \mathrm{~km})$, the Garonne is the fourth ranking river in France. The Garonne catchment is also one of the six hydrographic basins that divide the French territory into administrative regions. This basin is subject to a mainly oceanic climate and is further influenced by Mediterranean and mountain climates. These climatic settings give rise to a complex rain-snow regime (Pardé, 1928). The Garonne's hydrogeomorphological dynamic evolves in an upstream-downstream direction as the valley slope decreases and Atlantic influence increases (Fig. 1; Deffontaines, 1932; Lambert, 1989; Mergoil, 1993; Valette, 2002). The upper Garonne, mainly fed by Pyrenean tributaries, is characterized by steep slopes 
and an unstable confined channel. This section comprises the upper portion of the catchment that extends to the confluence with the Ariège River in Toulouse-Portet. The downstream section of the Garonne, from the confluence of the Dropt in Castets-en-Dorthe to the Gironde estuary, is the section subject to tidal influence. The so-called middle Garonne, between the upper and tidal sections, is characterized by a widening of the valley and an unstable channel increase. Located within the middle Garonne, the study reach is known as the Toulouse middle Garonne; it flows between the confluence of the Ariège River in Toulouse-Portet and the confluence of the Tarn in Moissac (Fig. 1; Table 1) and is characterized by its hydrogeomorphological homogeneity (Lambert, 1989). The Toulouse middle Garonne drains a total area of more than $15,200 \mathrm{~km}^{2}$, which represents $27 \%$ of the total area of the Garonne catchment.

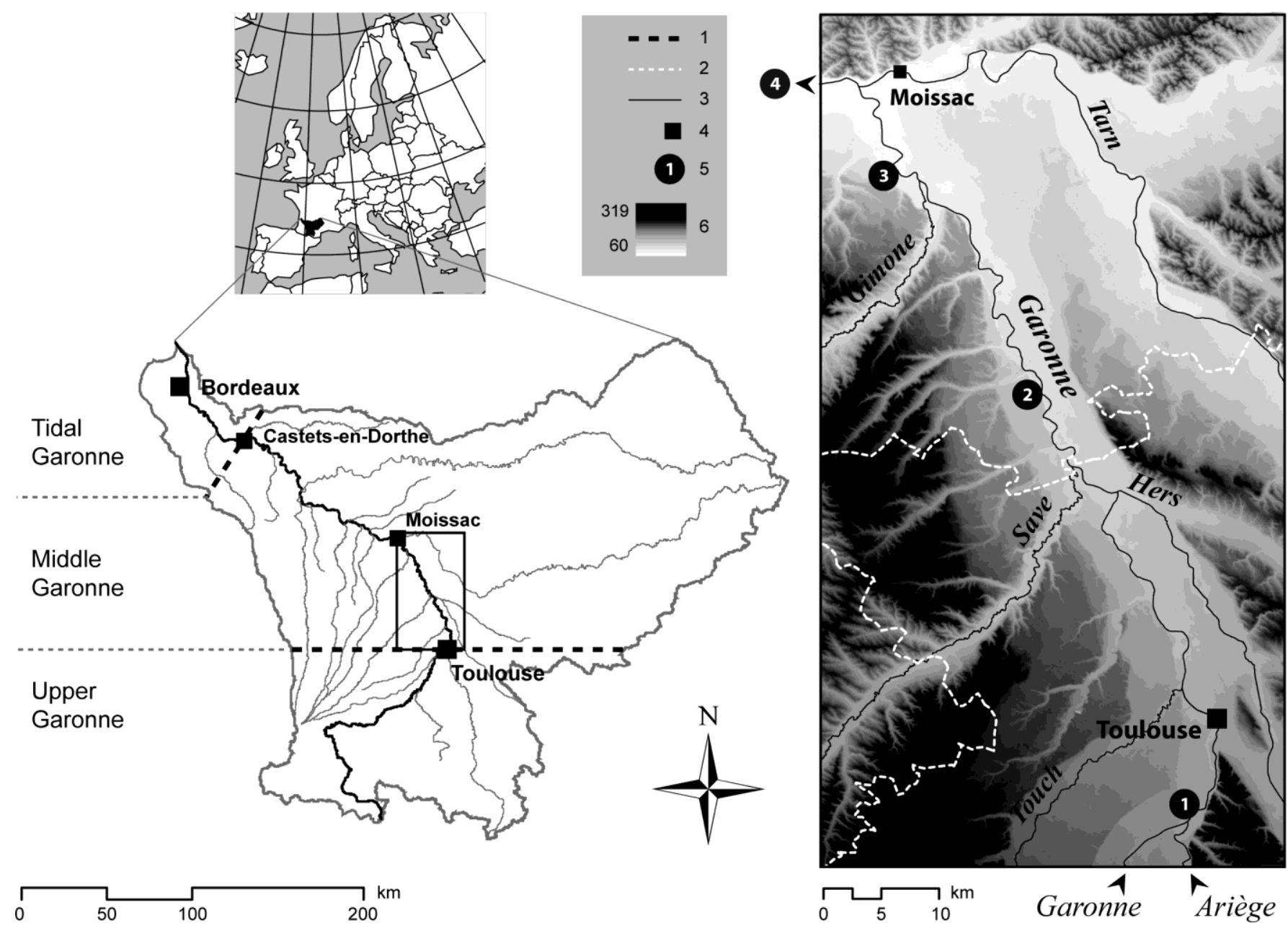

FIG1.TIF

\subsection{Geomorphology}

The Toulouse middle Garonne (Fig. 1; Table 1), 90 km long and oriented SE-NW, flows through 
a lower floodplain 2 to $4 \mathrm{~km}$ wide. Consisting of late Pleistocene to Holocene fluvial deposits, this lower floodplain is incised within a system of Pleistocene stair terraces. The river is a single-thread, sinuous channel (average sinuosity index along the entire reach: 1.3) and flows along the left-bank terrace, mainly over Miocene Molasse bedrock (crumbly sandstone and limestone from the Pyrenees foothill). The channel is on average $150 \mathrm{~m}$ wide and $4 \mathrm{~m}$ deep (Steiger and Corenblit, 2000). The slope remains steep in this section $\left(0.0009 \mathrm{~m} \cdot \mathrm{m}^{-1}\right.$ on average $)$ and the specific stream power is estimated between 60 and 75 W.m² (Steiger and Corenblit, 2000; Steiger et al., 2000), which allows the river to readjust following any corrective works undertaken on the watercourse (threshold set at $\sim 35 \mathrm{~W} . \mathrm{m}^{-2}$; Brookes, 1988). Except for the Hers-mort River, the main tributaries - the Touch, the Save, and the Gimone rivers - join the left-bank of the Toulouse middle Garonne.

\subsection{Hydrology and sediment supply}

The mean annual discharge of the Garonne (Table 1) is $189 \mathrm{~m}^{3} \cdot \mathrm{s}^{-1}$ at the Toulouse-Portet gauging station and undergoes a $200 \%$ increase downstream from the confluence with the Tarn. In contrast, the contribution of the main tributaries between Toulouse and the Tarn confluence (the Touch, Save, Hers, and Gimone rivers) is not significant, except during localized heavy rainfall. The complex rain-snow regime may generate violent and sometimes devastating floods (Table 1) at different times of the year: in spring, when rain events coincide with the Pyrenees snowmelt (e.g., the flood of 23 June 1875 - 100-year flood - with an estimated discharge of $7000 \mathrm{~m}^{3} . \mathrm{s}^{-1}$ in Toulouse-Portet); in winter, following 10-day rainy periods (e.g., the flood of 3 February 1952 with a discharge of $4350 \mathrm{~m}^{3} . \mathrm{s}^{-1}$ at the Toulouse-Portet gauging station and a recurrence interval of 50 years); or more rarely, in autumn when rainfall from the southwest adds to the flow of right-bank tributaries. The summer and winter low flows may also be severe (Table 1), giving rise to large molassic bedrock outcrops. Between Toulouse and the confluence of the Tarn, only $50 \%$ of the channel had alluvial cover in the 2000 s (Delmouly et al., 2007; Table 1), in contrast with the 11.7-m alluvial layer (boulders, cobbles, pebbles, and sand) which was observed in the Upper Garonne in 1981, $85 \mathrm{~km}$ upstream from Toulouse (Info Terre - dossier du sous-sol 10547X0086/S). To date, the bedload transport into the Toulouse middle Garonne consists mainly of silt. Sediment samples taken at 17 stations along the Toulouse middle Garonne after the flood of May 2005 were indeed comprised of $60 \%$ silt (Mamoudou, 2008). The total suspended load, 
quantified in the Toulouse middle Garonne between 2005 and 2007 (Mamoudou, 2008; Table 1) is 5 $\mathrm{mg} \cdot \mathrm{L}^{-1}$ on average during low-water periods (February 2005, October 2005, and September 2007) and $160 \mathrm{mg} \cdot \mathrm{L}^{-1}$ on average during peak flood periods (March 2005, May 2005, and May 2007). The tributaries of the Toulouse middle Garonne have negligible influence on these values, unlike the Tarn which considerably increases the suspended load by about $300 \%$ during flood periods.

\begin{tabular}{|c|c|c|c|c|c|}
\hline \multicolumn{6}{|l|}{ HYDROLOGY } \\
\hline \multirow{2}{*}{$\begin{array}{l}\text { Gauging station } \\
\text { Measurement period (years) }\end{array}$} & $\begin{array}{r}\text { Toulouse- } \\
\text { Portet }\end{array}$ & $\begin{array}{l}\text { Verdun-sur- } \\
\text { Garonne }\end{array}$ & Saint-Aignan & Lamagistere* & References \\
\hline & 105 & 43 & - & 48 & HYDRO \\
\hline$A_{d}\left(k^{2}\right)$ & 9980 & 13,730 & 15,200 & 32,350 & HYDRO \\
\hline$Q_{m}\left(m^{3} \cdot s^{-1}\right)$ & 189 & 193 & - & 395 & HYDRO \\
\hline$Q_{\min }\left(m^{3} \cdot s^{-1}\right)$ & 65 & 58 & - & 104 & HYDRO \\
\hline$Q_{5}\left(\mathrm{~m}^{3} \cdot \mathrm{s}^{-1}\right)$ & 2200 & 2700 & - & 3700 & HYDRO \\
\hline$Q_{20}\left(\mathrm{~m}^{3} \cdot \mathrm{s}^{-1}\right)$ & 3100 & 3700 & - & 5000 & HYDRO \\
\hline$Q_{50}\left(m^{3} \cdot s^{-1}\right)$ & 3600 & 4400 & - & 5800 & HYDRO \\
\hline$Q_{100}\left(m^{3} \cdot s^{-1}\right)$ & 7000 & - & - & - & Lambert, 1989 \\
\hline \multicolumn{6}{|c|}{ *16 km downstream from the Tarn River confluence } \\
\hline \multicolumn{6}{|l|}{ GEOMORPHOLOGY } \\
\hline Study area & \multicolumn{2}{|c|}{ Toulouse middle Garonne } & & & References \\
\hline$L(\mathbf{k m})$ & & 93 & & & IGN (Scan25) \\
\hline$S I$ & & 1.31 & & & IGN (Scan25) \\
\hline$W_{\mathrm{m}}(\mathrm{m})$ & & 150 & & & Steiger and Corenblit, 2000 \\
\hline$Z_{m}(m)$ & & 4 & & & Steiger and Corenblit, 2000 \\
\hline$S_{m}\left(\mathrm{~m} \cdot \mathrm{km}^{-1}\right)$ & 0.9 , i.e., 0.0 & $9 \%$ or $0.052^{\circ}$ & & & Steiger and Corenblit, 2000 \\
\hline$\omega\left(\mathbf{W} \cdot \mathrm{m}^{-1}\right)$ & & {$[60-75]$} & & & Steiger and Corenblit, 2000 \\
\hline \multicolumn{3}{|l|}{ SEDIMENT LOAD } & \multicolumn{2}{|c|}{ Middle Garonne downstream } & \\
\hline Study area & \multicolumn{2}{|c|}{ Toulouse middle Garonne } & from the $T$ & arn confluence & References \\
\hline Alluvial cover (\%) & & 50 & & - & Delmouly et al., 2007 \\
\hline \multicolumn{2}{|c|}{$S L C_{\mathrm{m}}$ during low-water periods $\left(\mathrm{mg} \cdot \mathrm{L}^{-1}\right.$ ) } & 5 & & 11 & Mamoudou, 2008 \\
\hline \multicolumn{2}{|c|}{$S L C_{\mathrm{m}}$ during peak flood periods $\left(\mathrm{mg} \cdot \mathrm{L}^{-1}\right)$} & 160 & & 460 & Mamoudou, 2008 \\
\hline
\end{tabular}

\section{TABLE1.TIF}

\subsection{Historical changes}

From at least the Middle Ages and until the mid-nineteenth century, the Toulouse middle Garonne was subject to river management practices for navigation improvement and/or agricultural land expansion (Valette, 2002). Numerous historical documents have shown that these actions were often ineffective owing to channel instability caused by the river's strong flood dynamics (Valette and Gazelle, 2000; Valette, 2002; Valette et al., 2014). 
In 1856, the opening of the lateral canal to the Garonne River and the arrival of the railways changed the way in which the Toulouse middle Garonne was used and managed. The transport of people and goods was facilitated in the valley, and this led to a decline in river navigation. As a consequence, public works undertaken to manage the channel decreased (Valette, 2002; Valette et al., 2014). At the same time, the water levels recorded at Toulouse (Fig. 2B) show a decrease in floods magnitude, which may be a response to the climate transition between the LIA and GW. Indeed, since the centennial flood of 1875 , the water level has never reached $5 \mathrm{~m}$ at Toulouse.

As of the end of the nineteenth century, dams were constructed at the headwaters (Fig. 2C), first to distribute water in the driest areas of the catchment and then for hydropower production and water supply. Simultaneously, the upper catchment experienced forest growth as a result of both the reforestation following rural decline and the implementation of policies for erosion control (Restauration des Terrains de Montagne). During the twentieth century, the construction of hydropower dams was generalized to the entire upper catchment and the Toulouse middle Garonne was progressively controlled and exploited. In-stream gravel extraction became intensive between the 1960s and the 1990s (Fig. 2D) before this practice was banned. According to Beaudelin (1989), 12 million tons of gravel were extracted from the riverbed of the middle Garonne between Toulouse and the departmental boundary of the Lot-et-Garonne ( 100 km in length) from 1965 to 1985, i.e., $4000 \mathrm{~m}^{3} \cdot \mathrm{km}^{-1} \cdot \mathrm{y}^{-1}$. At the same time, $32.5 \mathrm{~km}$ of banks were protected in the downstream part of the Toulouse middle Garonne in the department of the Tarn-et-Garonne (1960-1984; Fig. 2E) and the former dikes in the city of Toulouse (3.5 km) were extended for 12.5 km (1957-1997; Fig. 2E; Valette, 2002; Valette et al., 2014).

These disturbances had a considerable impact on the morphodynamics of the Toulouse middle Garonne. Bed lowering (by removal of alluvial cover and bedrock incision) is the primary process involved, which was estimated to be $4.8 \mathrm{~cm} \cdot \mathrm{y}^{-1}$ on average between 1960 and 1980, (i.e., nearly $1 \mathrm{~m}$ over 20 years; Steiger et al., 2000). This phenomenon is particularly severe in the upstream part of the Toulouse middle Garonne, where the exposed bedrock areas are dominant (Steiger et al., 2000). Incision was accompanied by a disconnection between the main channel and adjacent active channel areas (Valette, 2002; DDE 81, 2006). In addition, channelization and an increase in the severity and frequency of low flows were recorded beginning in the 1960s (Steiger et al., 1998) and additional 
phenomena were identified, such as a lowering of the water table and a decrease in the frequency of overbank events. Changes in the floodplain, especially the decline of the alluvial forest were interpreted as a consequence of this evolution (James, 1996; Steiger et al., 1998).

Apart from the shift in the 1960s, several parameters suggest that changes in the Toulouse middle Garonne's morphodynamics began before the mid-twentieth century: exposed bedrock areas in the channel were observed by the end of the nineteenth century (Harlé, 1895); a slight incision was documented as of the early twentieth century (Steiger et al., 2000); an active-belt narrowing has been observed over the last 200 years (Valette, 2002); and a reduction in channel length has occurred over the last 100 years (Steiger et al., 2000).

To date, no global restoration project has been carried out in the Toulouse middle Garonne. Only a few localized interventions were performed, mainly consisting in restoring and maintaining the connectivity of some former channels and preserving riparian vegetation. 

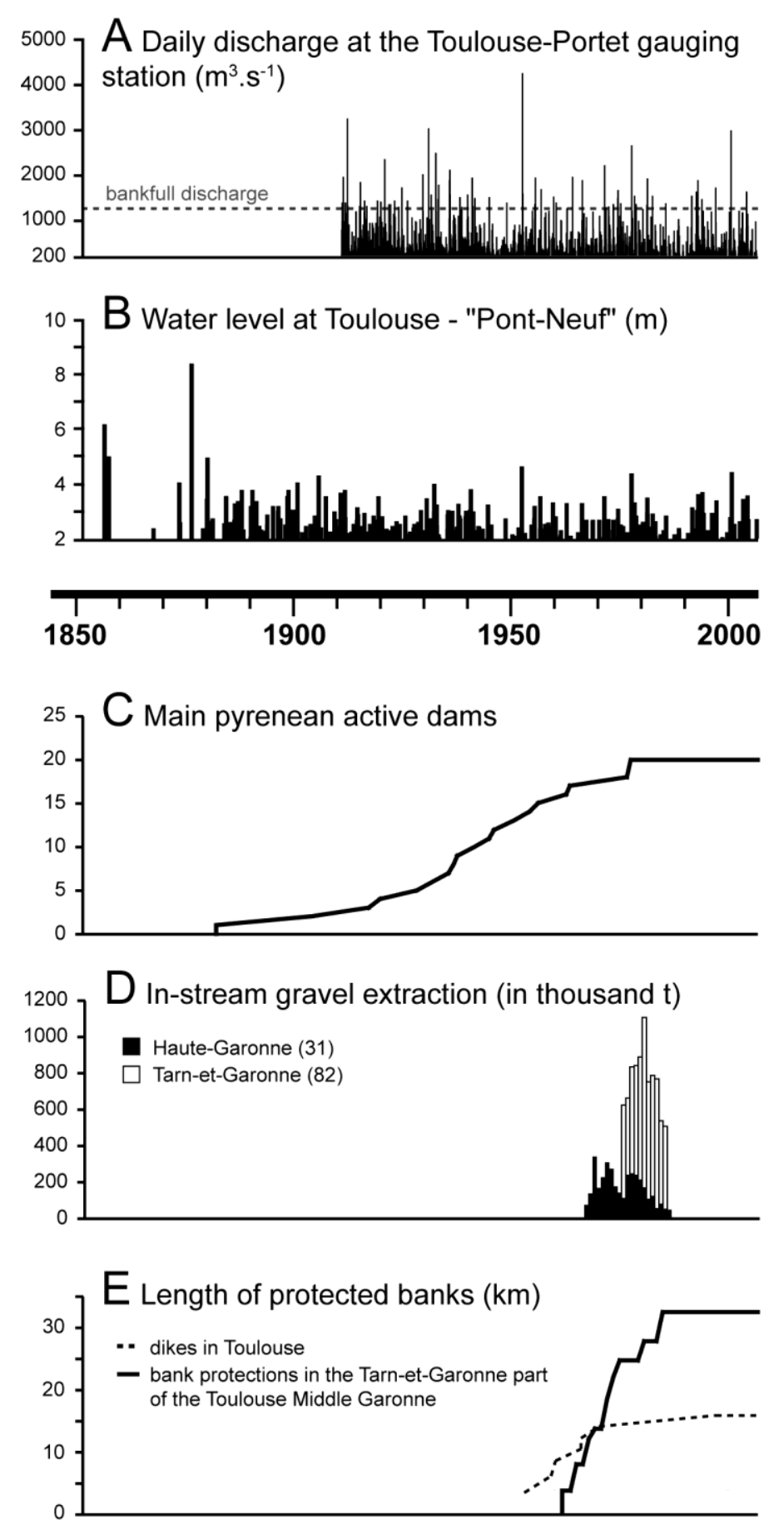

FIG2.TIF

\section{Materials and methods}

Figure 3 shows the different steps in the methodology, based on historical maps, adopted to study the evolution of channel planforms in the Toulouse middle Garonne. 


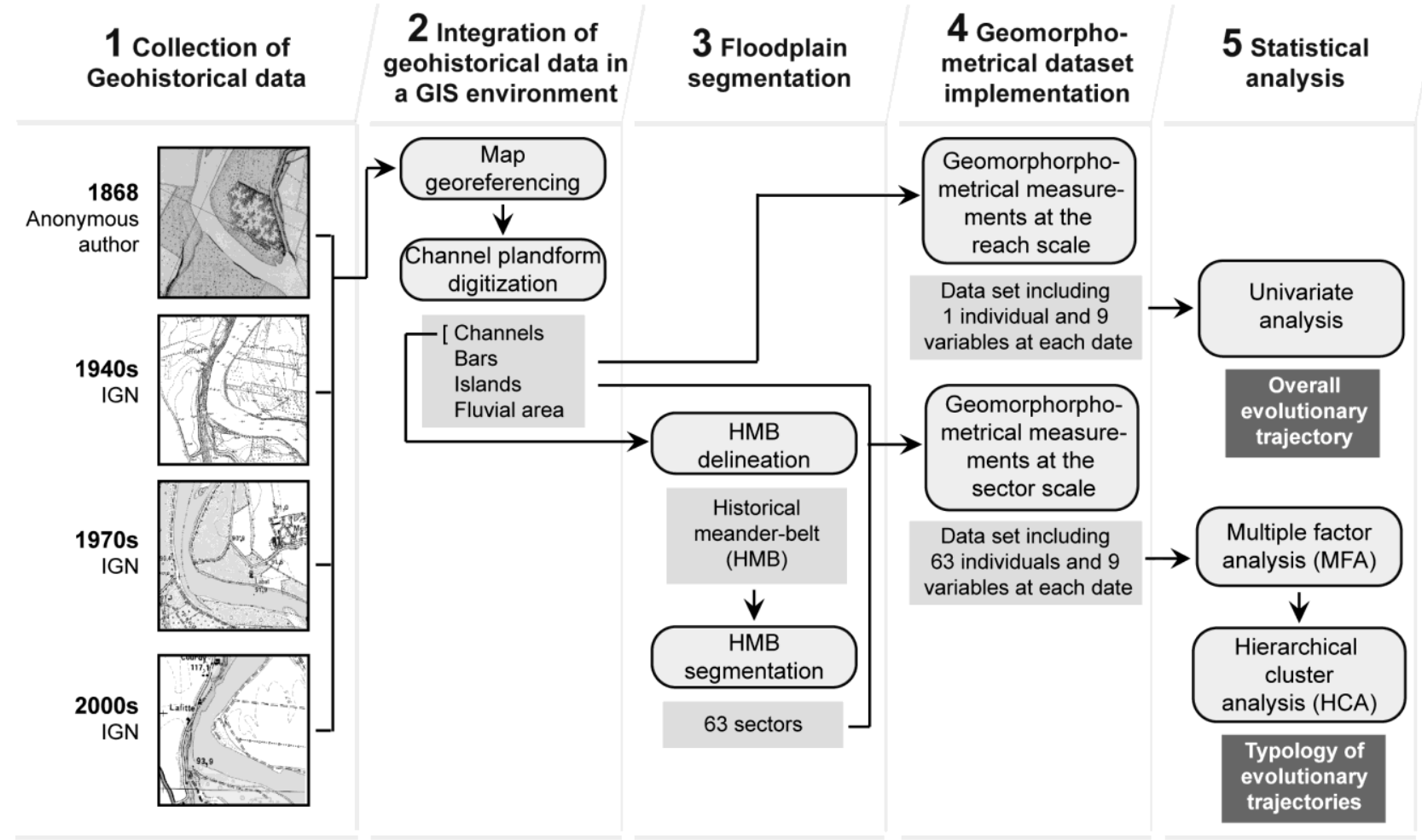

FIG3.TIF

\subsection{Collection of geohistorical data}

To document the evolution of channel planforms, historical maps obtained from various archives (national, university, Voies Navigables de France and Directions Départementales du Travail; Valette, 2004) were studied. The initial corpus includes 12 maps and/or sets of maps of the Garonne, dating from the beginning of the eighteenth century to the 2000s. All of them cover the entire section of the river between Toulouse and the confluence of the Tarn. Among them, four documents (or sets of documents) present a sufficient level of precision and accuracy to allow a quantitative analysis over a period of 130 years, from 1868 to the 2000s (Figs. 3, 4; Table 2). The first is an anonymous map at 1:10,000 dated 1868 that stands out by its quality and level of precision clearly superior to other nineteenth century maps. Then two sets of maps have been produced by IGN in the 1940s and 1970s, respectively, at scales from $1: 5000$ to $1: 25,000$. Finally, the last document is the referential for the 2000s (SCAN 25®), drawn between 2002 and 2006 at 1:25,000 and georeferenced by IGN.

The maps published by IGN in the 1940s and 1970s are among the most precise documents available for the twentieth century. However, a disadvantage of these data is the heterogeneity of dates 
and scales (Fig. 4). An initial series of plates was produced between 1940 and 1941 at 1:5000 for the Tarn-et-Garonne part of the study reach and between 1948 and 1950 at 1:20,000 for the HauteGaronne section. Two decades later, a set of maps covering the entire study reach at a scale of 1:25,000 was progressively published between 1971 and 1978, based on revisions of the earlier maps of the 1940s. From historical aerial photographs (Geoportail) and flow data (HYDRO), we have inferred that these sets of maps, respectively, provide representative views of the Garonne planforms over the 1940s and 1970s. Indeed, no change was observed in channel planforms between 1940 and 1948-50, nor between 1971 and 1978, according to available aerial photographs. Moreover, the 1940s were marked by a series of minor floods (Fig. 2A). During this period, only four floods reached or exceeded the bankfull discharge, i.e., $1300 \mathrm{~m}^{3} \cdot \mathrm{s}^{-1}$, compared to 11 over the $1930 \mathrm{~s}$ and 6 over the $1950 \mathrm{~s}$. The highest peak discharge over the 1940s was only $1930 \mathrm{~m}^{3} \cdot \mathrm{s}^{-1}$, opposed to $3050 \mathrm{~m}^{3} \cdot \mathrm{s}^{-1}$ over the $1930 \mathrm{~s}$ and $4300 \mathrm{~m}^{3} \cdot \mathrm{s}^{-1}$ over the $1950 \mathrm{~s}$. 

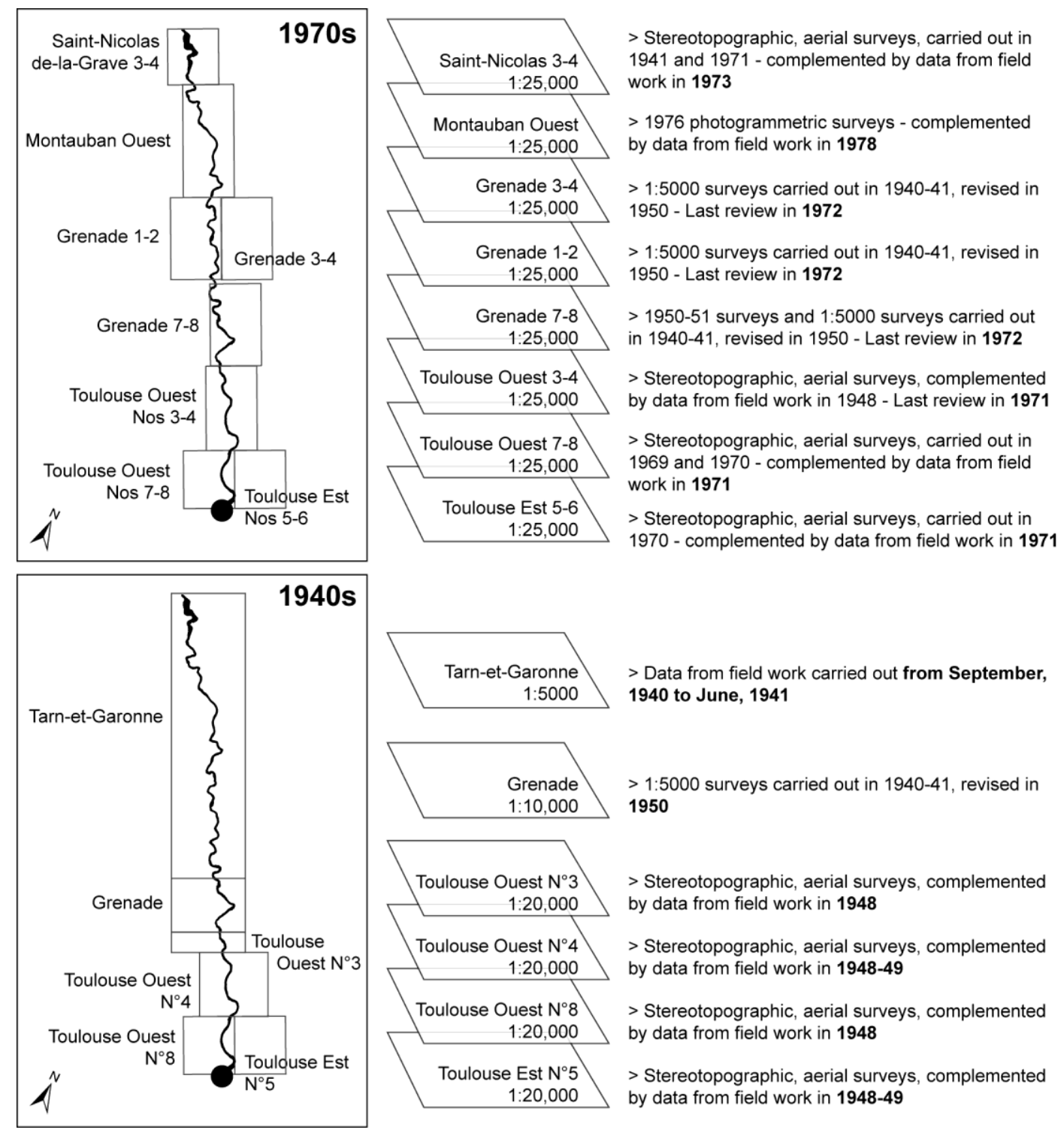

> Data from field work carried out from September,

$1: 5000$

1940 to June, 1941

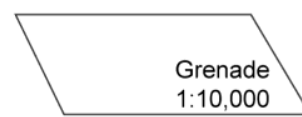

$>1: 5000$ surveys carried out in 1940-41, revised in 1950

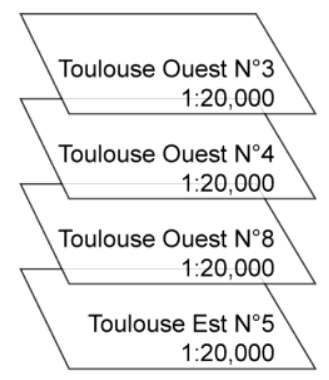

> Stereotopographic, aerial surveys, complemented by data from field work in 1948

$>$ Stereotopographic, aerial surveys, complemented by data from field work in 1948-49

> Stereotopographic, aerial surveys, complemented by data from field work in 1948

$>$ Stereotopographic, aerial surveys, complemented by data from field work in 1948-49

FIG4.TIF

\subsection{Integration of geohistorical data in a GIS environment}

The maps of 1868, the 1940s, and the 1970s were georeferenced (Table 2) using ArcMap ${ }^{\mathrm{TM}} 10$ GIS and first order polynomial transformation. When the map projection is known (maps of 1948-49, 1950, and 1970s), the $x$ and $y$ coordinates were assigned using the initial projection; the map was then reprojected using Lambert 93. In the case of the maps of 1868 and 1940-41, the projection is unknown; the maps were thus georeferenced onto a base map (SCAN $25 \AA)$ by selecting ground control points (GCPs) on the map to be warped and on the SCAN $25 \AA$. The root mean square (RMS) errors for the three groups of documents $(1868,1940 \mathrm{~s}$, and 1970s) range from 0.65 to $14 \mathrm{~m}$ with a sufficient number of GCPs (>0.5 GCP/km²). 


\begin{tabular}{|c|c|c|c|c|c|c|c|c|c|c|}
\hline & $\begin{array}{l}\text { Survey or } \\
\text { last review }\end{array}$ & Scale & $\begin{array}{c}\text { Initial } \\
\text { number } \\
\text { of } \\
\text { images }\end{array}$ & $\begin{array}{c}\text { Pre- } \\
\text { treatment }\end{array}$ & $\begin{array}{l}\text { Number of } \\
\text { geo- } \\
\text { referenced } \\
\text { images }\end{array}$ & $\begin{array}{l}\text { Geo- } \\
\text { referencing } \\
\text { method }\end{array}$ & $\begin{array}{c}\text { Total } \\
\text { area } \\
\text { covered } \\
\left(\mathbf{k m}^{2}\right)\end{array}$ & $\begin{array}{l}\text { Number } \\
\text { of GCPs }\end{array}$ & $\begin{array}{c}\text { Number } \\
\text { of GCPs } \\
/ \mathrm{km}^{2}\end{array}$ & $\begin{array}{l}\text { Average } \\
\text { RMS error } \\
\text { (m) }\end{array}$ \\
\hline 2000s & 2002-2006 & $1: 25,000$ & 18 & - & - & - & - & - & - & - \\
\hline 1970s & 1971-1978 & $1: 25,000$ & 8 & division & 21 & $x$ and $y$ & 423 & 301 & 0.71 & [0.65-1.89] \\
\hline \multirow{2}{*}{ 1940s } & 1950 & $1: 10,000$ & 1 & division & 3 & $x$ and $y$ & 21 & 27 & 1.29 & [1.17-2.04] \\
\hline & $1940-1941$ & $1: 5000$ & 56 & - & 56 & base map & 167 & 506 & 3.03 & [1.11-6.33] \\
\hline 1868 & $\sim 1868$ & $1: 10,000$ & 8 & division & 61 & base map & 370 & 555 & 1.50 & [3.86-14] \\
\hline
\end{tabular}

TAB2.TIF

The channel planforms were digitized from the four maps $(1868,1940$ s, 1970s, and 2000s; Fig. 5A) using ArcMap ${ }^{\mathrm{TM}} 10$ GIS. We distinguished (i) the wetted channel, which is the underwater channel on maps; (ii) the vegetated islands, i.e., deposits with vegetation cover, which separate the main channel from a secondary flow; (iii) the exposed bars, i.e., sand or gravel bars, lateral or central or alongside an island, with no vegetation cover; and (iv) the fluvial area, encompassing the active-belt (i.e., main channel and bars), secondary active channels, and islands. The choice of these items was based on how well they represent the river's hydrosedimentary behavior and whether they are simple enough to allow for a multisource approach.

In any study involving historical sources, the results are inevitably associated with some uncertainty, in terms of positional, temporal, and attribute accuracies (Gurnell et al., 2003; Payraudeau et al., 2010). One source of uncertainty depends on the initial mapping of the channel on historical maps. In this study, we assume that the boundaries of the wetted channel are representative of an average discharge. In fact, the effective dates at which the maps were surveyed are unknown, which prevents assessment of the exact value of the figured discharge. However, we compared areas of exposed bars/bedrock shown on the IGN maps (1940s, 1970s, and 2000s) with precisely dated aerial photographs from the same periods (Geoportail) that can be associated with the flow data recorded at the Toulouse-Portet gauging station (HYDRO). The areas of exposed bars/bedrock shown on the maps are systematically larger than they are in the photographs of floods and smaller than they are in the photographs of low flows. We could therefore infer that IGN cartographers wanted to minimize effects of varying water level between dates of aerial surveys by delineating the wetted channel for an average discharge, likely using data from field work. The method used to define the channel boundaries on the 
1868 map remains more uncertain.

\subsection{Floodplain segmentation}

The historical meander-belt (HMB) encompassing the channel at the four periods was delineated and subdivided into subreaches or sectors $1 \mathrm{~km}$ in length, following a semiautomatic method (Alber and Piégay, 2011) ${ }^{1}$. The use of this method to analyze planform adjustments is limited in that the sectors have irregular shapes whereas the HMB forms an angle. One part of the polygon is then shorter than the other, leading to measured areas of varying sizes, depending on the channel position within the sector. The method has been adapted here to allow a constant measured area from year to year, despite lateral riverbed migration: the sectors are perpendicular to the HMB central axis and geometrically identical; when the HMB forms an angle, instead of altering the shape of the polygons the sectors are slightly superimposed (Fig. 5B). A transect was traced in the center of each sector perpendicular to the HMB central axis to enable any one-time measurements (Fig. 5B).

The areas situated in immediate proximity to the historic quarter of Toulouse or to the confluence of the Tarn were excluded from analysis owing to the large human impact potentially influencing the multivariate analysis. In all, 63 sectors (S1-S63) were used in the analysis.

\subsection{Geomorphometrical data set implementation}

Nine geomorphometrical parameters were measured/calculated at the sector scale for each date on the channel planforms digitized above (Fig. 5 - C). Three of these parameters were measured on the channel once per transect: the width of the wetted channel (WCW, in m, encompassing the width of the main channel and the widths of the secondary channels), the number of secondary channels (SC) and the width of the fluvial area (FAW, in $\mathrm{m}$ ). These measurements were carried out perpendicular to the median axis of the wetted channel (in the case of WCW and SC) or perpendicular to the median axis of the fluvial area (in the case of FAW) at the point where these axes are intersected by the transects. Two parameters were measured on the islands and bars: the total area of vegetated islands

\footnotetext{
$1 \quad$ An alternative method for generating sectors every kilometre is found in ArcMap ${ }^{\mathrm{TM}} 10$, the tool 'Create an
} index along a linear entity', found in 'Cartographic tools' > 'Dynamic pages'. 
(VA, in $\mathrm{km}^{2}$ ) and the total area of nonvegetated bars (NVA, in $\mathrm{km}^{2}$ ). The last four variables were measured on the morphological units used to indifferently analyze the islands and bars, i.e., considering an island and its lateral bars as a unique form: the size/area $\left(\mathrm{S}\right.$, in $\left.\mathrm{km}^{2}\right)$, the perimeter $(\mathrm{P}$, in $\mathrm{km})$, the nearest distance to a bank (ND, in $\mathrm{m}$ ), and the Gravelius index (G), which gives an indication as to the circularity of the morphological units. For these four parameters, the values integrated in the data set are averages.

Given the quality of the historical cartographic sources, numerous other variables might also have been measured, such as various rates of change, meander-bend wavelength, or curvature radius. For various reasons, however, we chose to focus on static variables describing the channel at the sector scale rather than at the scale of the meander-bend and on intermaps periods. Rates of change were avoided in order to approach the dynamic dimension through the multivariate analysis. In addition, variables related to meander bends were also avoided so as to allow a statistical analysis based on comparable units. This choice also depends on how the method could be reproduced on the estuarine part of the river within a larger study of the adaptation of the Garonne to global change (Adapt'eau and Gagilau projects).

To complete the results obtained by multivariate analyses, an additional data set was computed at the reach scale. In this data base, two parameters characterizing the channel (WCW and FAW) are average values of the measures taken every kilometer. The last variable characterizing the channel (SC) is a percentage of sectors with positive values. The parameters characterizing the islands and bars (VA and NVA) and the morphological units (S, P, G and ND) are raw values. Sinuosity (SI; Fig. 5C), was added to this scale by measuring the ratio between the median axis of the channel and the straight line between the two end points of the reach. This parameter was also tested at the sector scale but was not retained owing to its low importance in multivariate analysis. 

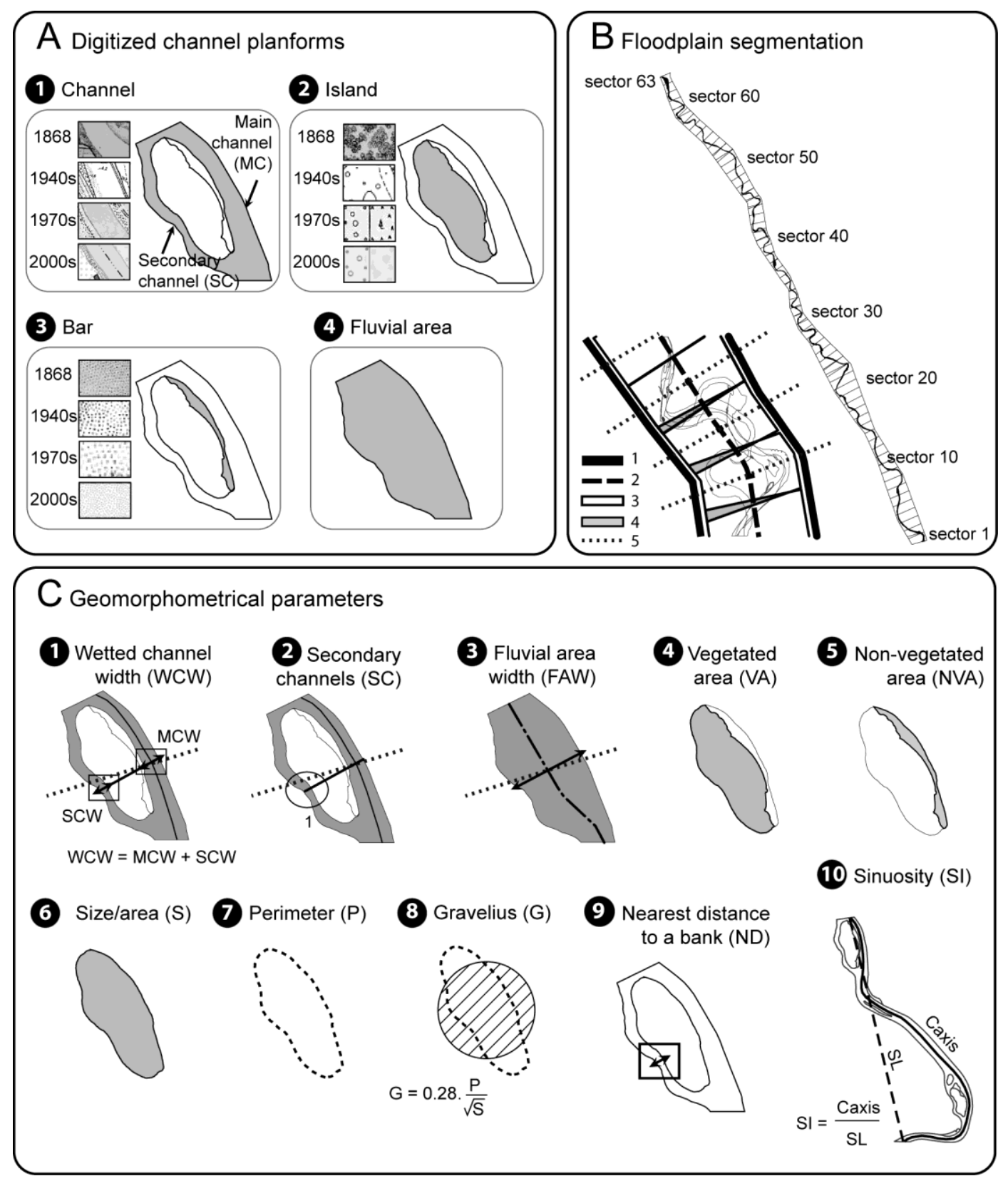

FIG5.TIF

\subsection{Statistical analysis}

The diachronic geomorphometric database generated at the sector level was processed using multiple factor analysis (MFA). Developed by Escofier and Pagès $(1994,1998)$ to analyze variables split into groups, MFA has (to date) been commonly used in ecology (e.g., Bensizerara et al., 2013; Puech et al., 2014). The principle is simple: each group of variables is first normalized using the first eigenvalue produced by a preliminary principal component analysis (PCA); a secondary PCA is then performed on all of the groups of weighted values. The normalization prevents a group of variables from dominating 
the global PCA through the inertia of its principal components. In this study, the data are organized in four groups, each of them corresponding to the date of the map in use.

The MFA was first developed for analyzing quantitative data and was then extended to the simultaneous processing of groups of quantitative or qualitative variables. The mixed MFA (MFAmix) developed by Chavent et al. (2012) allows groups of data containing quantitative and qualitative variables to be analyzed. In this study, the groups of variables contain mainly quantitative data; but one of the nine parameters, the secondary channels (SC), was encoded as a qualitative variable (absence/presence) because of the homogeneity of the collected values. A bias was observed in the data group from the 1940s map: SC is highly dependent on transect location (fragmentation of islands and bars) and, thus, was not taken into account for processing in the present investigation.

The results of MFAmix were described by using hierarchical cluster analysis (HCA) in order to identify groups of sectors sharing common characteristics. The HCA was performed using values of mean individuals on the first 10 factors/axes of the MFAmix, which represent $80 \%$ of the inertia. The number of classes retained depends on the dendrogram; their interpretation is based on the automatic calculation of the value test $(T)$ associated with each variable within each class (Eq. 1). A variable is considered to be characteristic within a class if its associated test value is superior to 2 .

$$
T=\frac{\mu b-\mu}{\sqrt{\frac{\eta-\eta}{\eta-1} \times \frac{\sigma^{2}}{\eta}}}
$$

With:

$T$ the value test,

$\eta$ the total number of individuals,

$\eta_{\vartheta}$ the number of individuals in the class $\vartheta$

$\mu$ the variable average calculated on the basis of all individuals,

$\mu_{\vartheta}$ the variable average calculated on the basis of the individuals of the class $\vartheta$, and 
$\sigma$ the standard deviation of the variable calculated from all individuals.

\section{Results}

\subsection{Univariate descriptive analysis}

At the level of the entire study reach, the parameters describing the channel (SI, SC, WCW, and FAW; Figs. 6A, C and D) and those related to the islands and bars (VA and NVA; Fig. 6B) show overall simplification and homogenization of the river bed throughout the period from 1868 to the 2000 s. The sinuosity (SI) slightly decreased (from 1.33 to 1.27 , i.e., $-0.0004 . y^{-1}$ on average), with a more sustained rhythm between the 1940 s and 1970 s $\left(-0.010 \cdot y^{-1}\right.$ on average). Despite this evolution, the Garonne remained in the $[1.25<\mathrm{SI}<1.50]$ range of so-called highly sinuous channels. Islands and bars experienced a more significant evolution. In 1868 islands and bars covered a surface of $3.68 \mathrm{~km}^{2}$ and $2.96 \mathrm{~km}^{2}$, respectively (i.e., 21 and $17 \%$ of the fluvial area). By the $2000 \mathrm{~s}$, their surfaces had reduced to 0.37 and $0.34 \mathrm{~km}^{2}$, respectively (i.e., a total of $6 \%$ of the fluvial area). The total surface loss over the 130 -year period corresponds to $3.30 \mathrm{~km}^{2}$ for the islands and $2.60 \mathrm{~km}^{2}$ for the bars. The reduction in the total surface occupied by islands was progressive throughout the period, with an average rate of decline of $0.025 \mathrm{~km}^{2} \cdot \mathrm{y}^{-1}$, whereas the reduction in the total area occupied by bars began only after the 1940s and became obvious between the 1940s and 1970s with an average rate of decline of 0.060 $\mathrm{km}^{2} \cdot \mathrm{y}^{-1}$. The decrease in the area covered by islands was accompanied by a reduction in the number of secondary channels (SC) and a narrowing of the fluvial area (FAW): in 1868, 33\% of sectors counted at least one secondary channel compared to only $8 \%$ in the 2000 s; the fluvial area presented an average width of $237 \mathrm{~m}$ compared to only $137 \mathrm{~m}$ in the 2000 s (i.e., an average loss of $76 \mathrm{~cm}^{-1} \mathrm{y}^{-1}$ ). The wetted channel width (WCW), on the other hand, remained relatively stable throughout the study period. First characterized by a slight narrowing between 1868 and the 1940s, by the end of the period it then tended to widen, probably in response to adjustment of bars.

The sizes, shapes and positions of morphological units (S, P, G, and ND; Figs. 6E- H) followed more complex evolutions, reflecting a homogenization of channel planforms, mainly visible at the end of the period. Two tendencies become apparent: (i) a dominant pattern of islands and/or bars of relatively homogenous size, shape, and position enduring over the entire study period (reduced ranges between 
Q1 and Q3); and (ii) exceptional individuals, presenting extreme maximal values between the 1970s and 2000 s, dramatically decreasing at the end of the period.

A Sinuosity (SI)

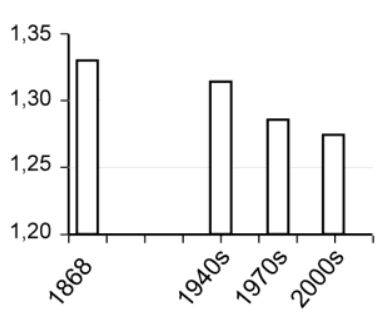

E Size/area (S, in $\left.\mathrm{km}^{2}\right)$

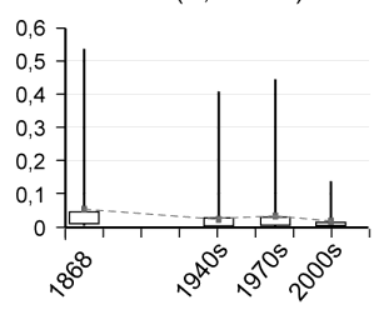

B Presence of secondary channels (SC, in \%)

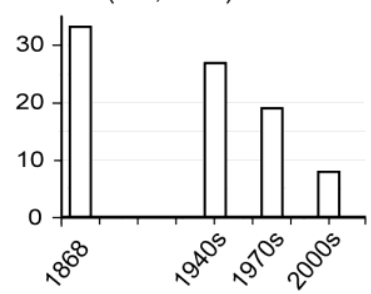

$\mathrm{F}$ Perimeter $(\mathrm{P}$, in $\mathrm{km})$

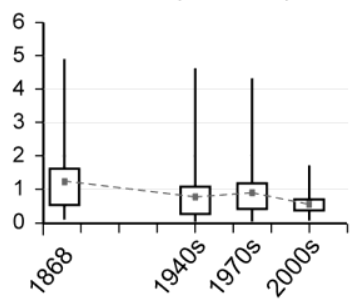

C

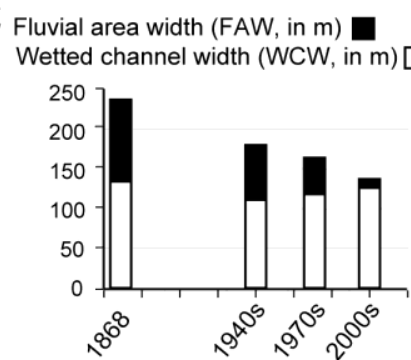

G Gravelius (G)

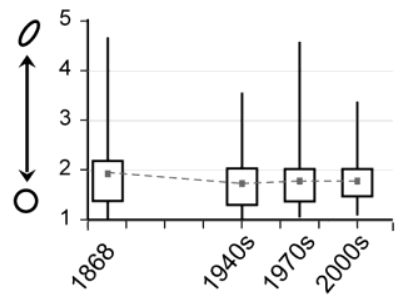

$\mathrm{D}$ Vegetated area $\left(\mathrm{VA}\right.$, in $\left.\mathrm{km}^{2}\right)$ Nonvegetated area (NVA, in $\left.\mathrm{km}^{2}\right)$

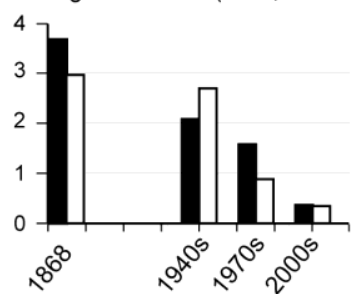

H Nearest distance (ND, in $\mathrm{m}$ )

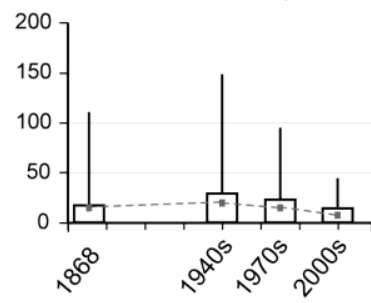

I Rates of change (raw values)

\begin{tabular}{|c|c|c|c|c|}
\hline Parameters & $186^{-194}$ & $19405^{-1}$ & $19705-200$ & Full period \\
\hline Sinuosity (SI, SI.y-1) & $-0,0002$ & $-0,0010$ & $-0,0004$ & $-0,0004$ \\
\hline $\begin{array}{l}\text { Vegetated area } \\
\left(\mathrm{VA} \text {, in } \mathrm{km}^{2} \cdot \mathrm{y}^{-1}\right)\end{array}$ & $-0,022$ & $-0,017$ & $-0,041$ & $-0,025$ \\
\hline $\begin{array}{l}\text { Nonvegetated area } \\
\left(\mathrm{NVA} \text {, in } \mathrm{km}^{2} \cdot \mathrm{y}^{-1}\right)\end{array}$ & $-0,004$ & $-0,061$ & $-0,018$ & $-0,020$ \\
\hline
\end{tabular}

\section{J Rates of change (average values)}

\begin{tabular}{|c|c|c|c|c|}
\hline Parameters & $1868-19$ & $194.05-1$ & $19705-200$ & Full perio \\
\hline Fluvial area width (FAW, in $\mathrm{m} \mathrm{y}^{-1}$ ) & $-0,79$ & $-0,53$ & $-0,90$ & $-0,76$ \\
\hline Wetted channel width (WCW, in m. $y^{-1}$ ) & $-0,32$ & $+0,23$ & $+0,27$ & $-0,06$ \\
\hline Size/area $\left(\mathrm{S}\right.$, in $\left.\mathrm{m}^{2} \cdot \mathrm{y}^{-1}\right)$ & -347 & +263 & -635 & -274 \\
\hline Perimeter $\left(P\right.$, in $\left.m . y^{-1}\right)$ & -6 & +5 & -11 & -5 \\
\hline Gravelius (G, G.y $\left.y^{-1}\right)$ & $-0,002$ & $+0,002$ & 0 & $-0,001$ \\
\hline $\begin{array}{r}\text { Nearest distance to a bank } \\
\left(\mathrm{ND}, \text { in } \mathrm{m} \cdot \mathrm{y}^{-1}\right)\end{array}$ & $+0,10$ & $-0,18$ & $-0,23$ & $-0,04$ \\
\hline
\end{tabular}

FIG6.TIF

\subsection{MFA mix}

In order to emphasize key trends, the following interpretation is based on the first four principal components (or factors/axes) of MFAmix, which represent $50 \%$ of total variance (Fig. 7). This analysis highlights a distinction between sectors or dates where the channel is characterized by islands and those where the major channel features are related to bars.

Axis 1 represents $18 \%$ of total variance. Characterized mainly by variables related to vegetated islands in the 1940s and 1970s (FWA and VA), it is also positively correlated with sizes of morphological units in the 1970s (S). No negative correlation is observed on this axis. 
Axis 2 represents $12.8 \%$ of total variance and highlights a feature of the $2000 \mathrm{~s}$. Indeed, axis 2 is positively correlated with almost all variables of the 2000 s, especially size and shape of morphological units (P, S, and G), but also vegetated areas (VA) and secondary channels (SC). However, we should note that axis 2 is also negatively correlated with islands in 1868 (VA and FWA).

Axis 3 represents $11.3 \%$ of total variance. It is positively correlated with nonvegetated areas (NVA) throughout the period from 1868 to the 1970s and also with the Gravelius index (G) in the 1970s. Axis 3 is negatively correlated with the width of the wetted channel (WCW) in the 1970s. All of these correlations refer to bars, especially lateral ones of a particularly elongated shape.

Axis 4 represents $8.5 \%$ of total variance. It is positively correlated with variables related to the size of morphological units in the 1940s (PS) and to the Gravelius index in 1868. It is negatively correlated with variables related to islands in 1868 (FWA, VA, and ND). 

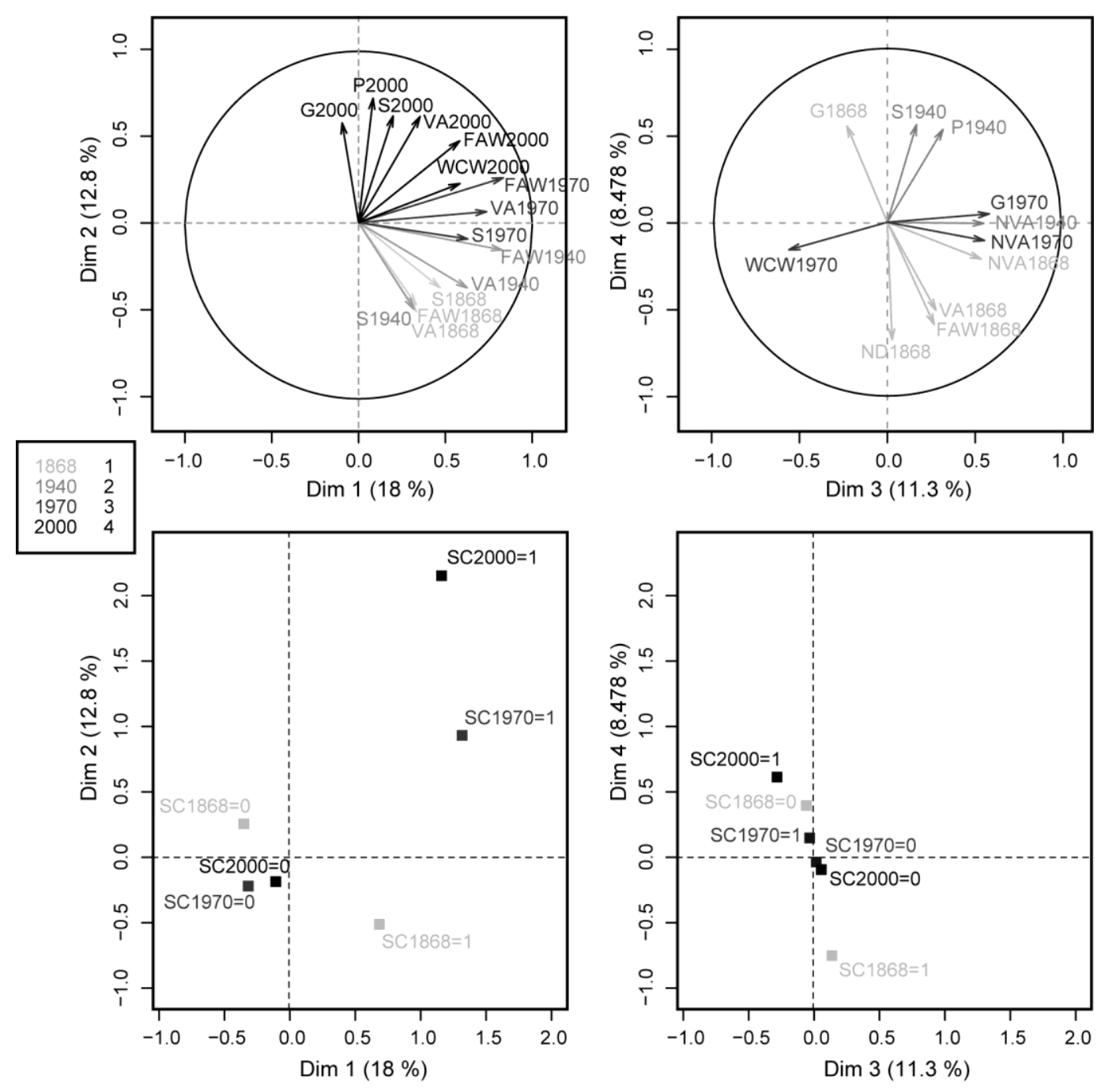

FIG7.TIF

\subsection{HCA}

While only the first four principal components of MFAmix were interpreted in the previous section, HCA was performed using the first 10 principal components, which represent $80 \%$ of total variance. In conformity with the dendrogram (Fig. 8A), seven classes were adopted. The characteristics of each class can be deduced from the test values associated with each variable (Fig. 8B).

Class 1 (18 sectors) brings together the sectors characterized by a wetted channel that was particularly wide from the 1940 s to the 2000s. At the beginning of the study period, these sectors included islands (no or few bars) of circular shape and small size situated far from the banks. Toward the end of the period, these sectors were especially marked by a wide fluvial area. 
Class 2 ( 6 sectors) includes the sectors covering large vegetated islands in the 1940 s. The channel planforms seen in these sectors were marked by an extended perimeter at the beginning of the study period which, in contrast, declined at the end of the period, tending toward a circular shape.

Class 3 (3 sectors) reveals a particularity of the 2000s, bringing together sectors which, at that time, covered large vegetated islands.

Class 4 (15 sectors) presents complex characteristics. It is marked by low values for numerous variables throughout the study period. This class appears to bring together parts of the study reach marked by a certain morphological simplicity throughout the study period.

Class 5 is comprised of a single sector, characterized by one or more large vegetated island(s) in the 1940s and 1970s. This/these island(s) was/were large in 1868 and in the 1970s.

Class 6 ( 8 sectors) reveals a particularity of 1868 . The relevant sectors were marked by large vegetated islands at that time. During that period the sectors were also characterized, to a lesser extent, by a wide wetted channel, the presence of bars, and a tendency toward circular morphological units.

Class 7 (12 sectors) includes sectors marked by the presence of bars throughout the study period. From the 1940 s to 2000 s, these landforms were particularly elongated and the wetted channel was narrow. In 1868, the sectors in this class were characterized by the low presence of islands. 


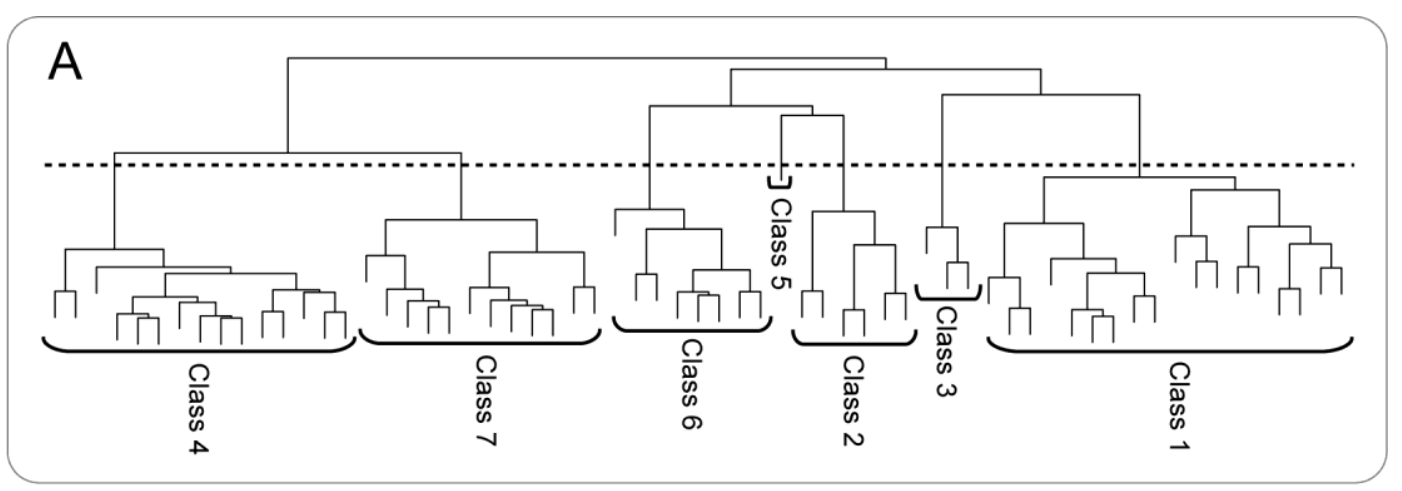

B
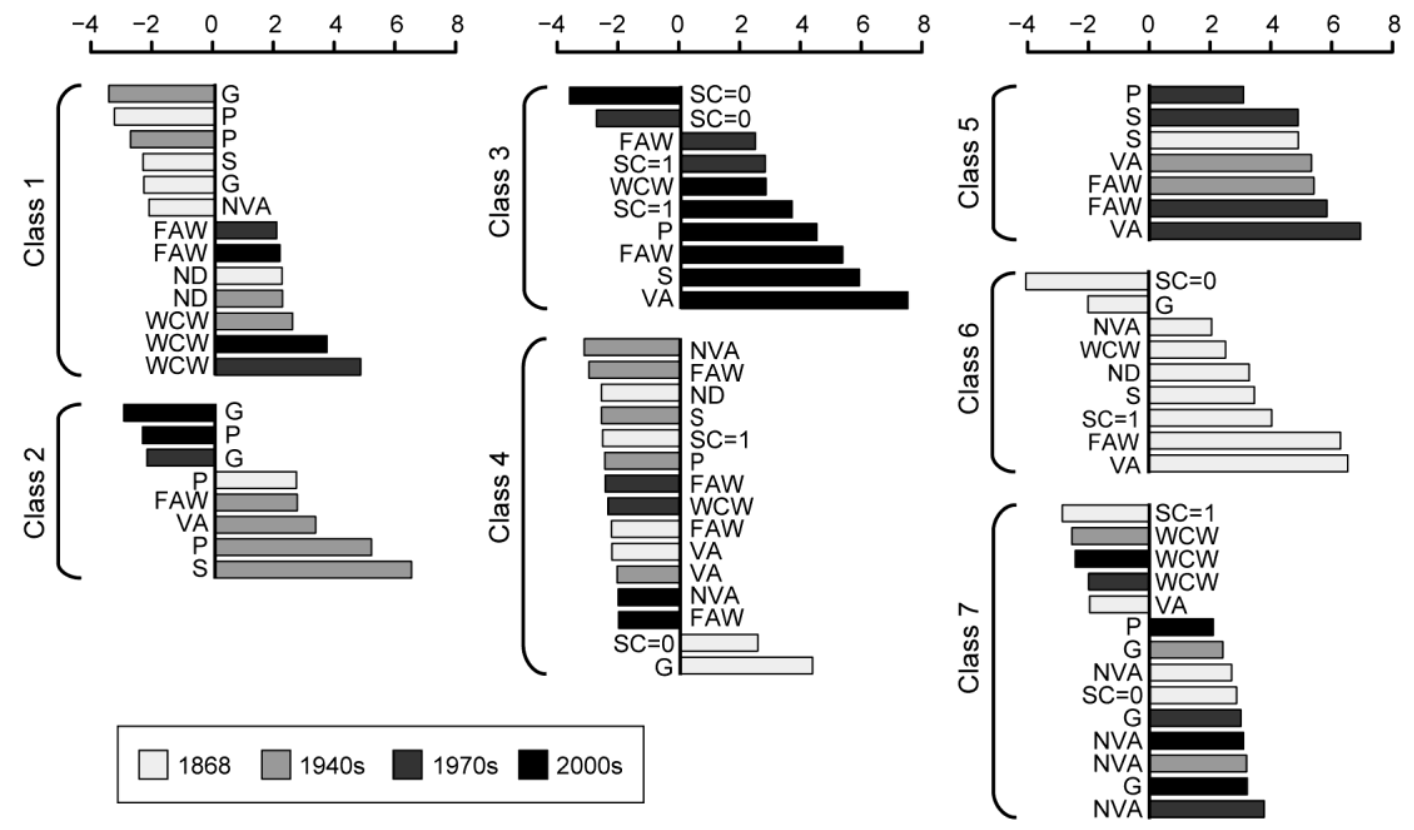

FIG8.TIF

\subsection{Spatialization of results along the study reach}

The cartography of the HCA results (Fig. 9) highlights the fact that the classes are not randomly distributed. The classes tend to aggregate into clusters or to form patterns along the study reach. This spatial distribution leads to a segmentation of the entire reach into four homogeneous zones (Z1 to Z4), each one characterized by the presence/dominance of one or several classes. In light of the typology established using HCA and by observing the digitized channel planforms, these zones may be interpreted in terms of evolutionary trajectories (Figs. 10-13). 


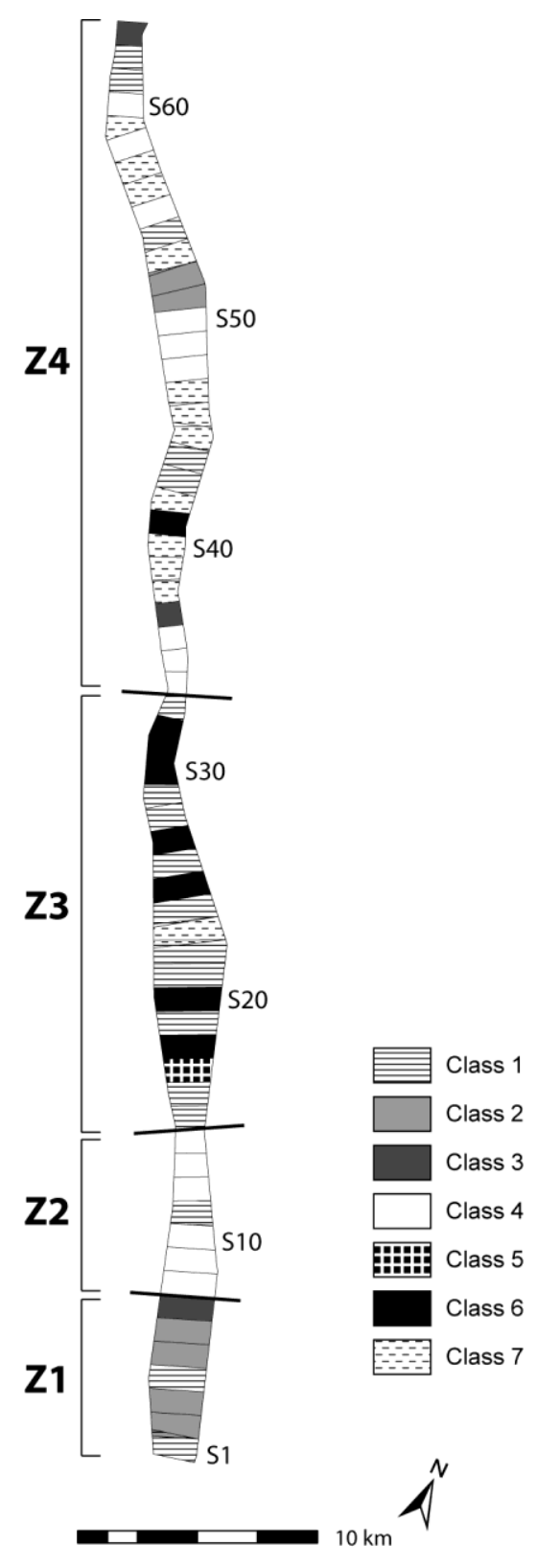

FIG9.TIF

Zone 1 (Z1), downstream from Toulouse $(7 \mathrm{~km})$, is dominated by class 2 (Fig. 10), which is characterized by the presence of elongated islands in the channel in the 1940s. Three islands were indeed apparent as early as 1868 , which progressively disappeared over the study period: Tounis, Amidonniers, and Pecette Islands. Tounis Island disappeared between 1868 and the 1940s, while Pecette Island experienced surface expansion. The major parts of these islands then disappeared between the 1940s and 1970s. Since the 1970s, Z1 as a whole presents a simple channel morphology. Only the newest part of Pecette Island is still present, which is highlighted by its inclusion in class 3 . In addition, we should note that in Z1 the channel appears to have been stable throughout the study period. 


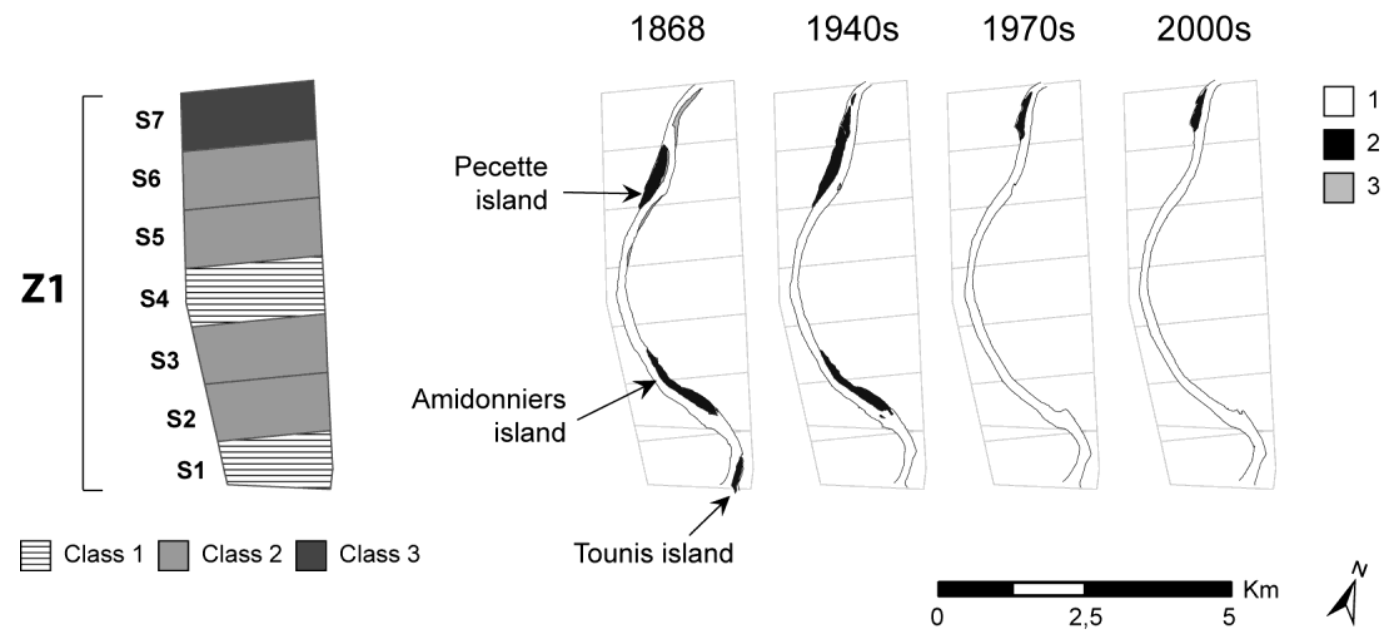

FIG10.TIF

Zone 2 (Z2) (7 km) stands out owing to the presence of class 4 (Fig. 11), which is associated to the morphological simplicity of the channel throughout the study period. In 1868 this zone contained a few islands and bars, especially elongated lateral bars. The only exception is $\mathbf{S 1 1}$, which presented a more circular bar noted for belonging to class 1 . Nearly all of the bars disappeared between 1868 and the 1940s, while during the same time the vegetated areas developed slightly. The islands then disappeared toward the end of the study period and the channel simplified dramatically. We should note that the channel tended to migrate laterally at the beginning of the study period between 1868 and the 1940s (e.g., at the so-called meander of the 'Quinze Sols'), then stabilized after the 1940s.

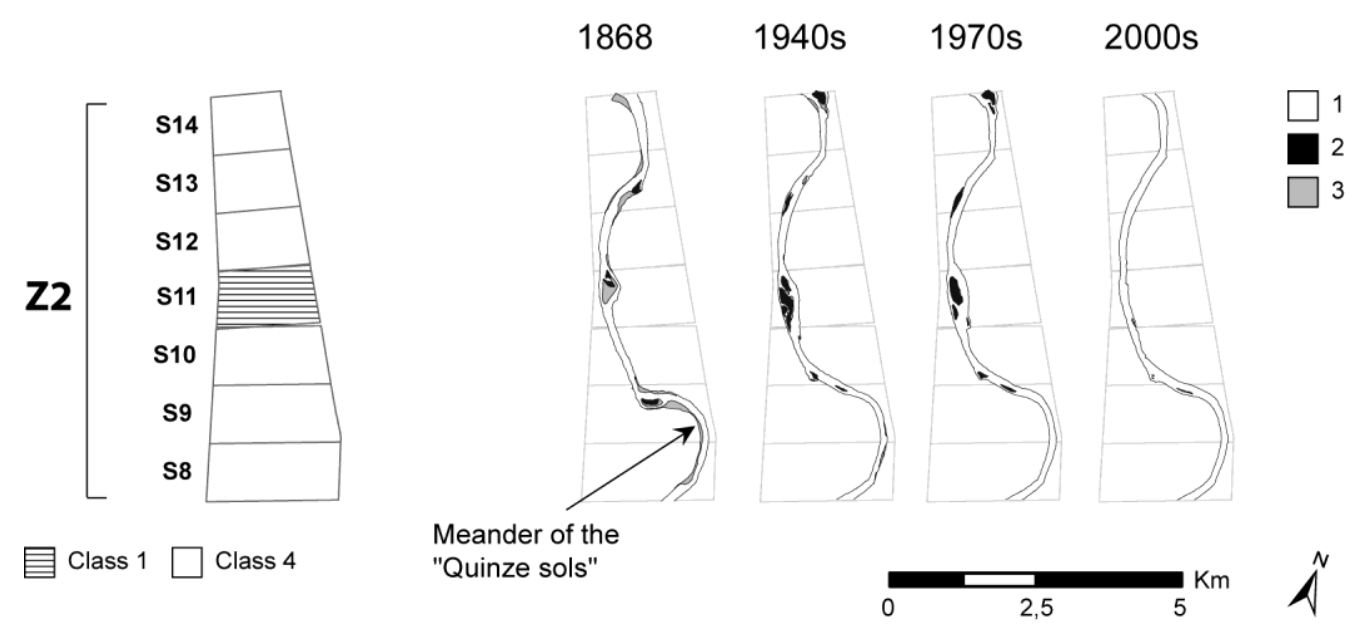

FIG11.TIF 
Zone $3(\mathrm{Z3})(19 \mathrm{~km})$ is distinctive for the presence/association of two classes that are rare in the other zones (Fig. 12): class 1, characterized by circular morphological units away from the banks at the beginning of the study period and by a wide wetted channel as of the 1940s; and class 6 , associated with large islands forming a wide fluvial area in 1868. Indeed, at the beginning of the study period, zone 3 included varied channel planforms: large islands separated from the bank by narrow channels, smaller islands farther from the bank, and also numerous bars, lateral or central or alongside an island. Between 1868 and the 1940s, nearly all the islands visible in 1868 disappeared to be replaced by just three large complexes of islands, though bars were still present. From the 1940s, channel simplification continued with the disappearance of Martignac and Mauvers Islands and a decrease in the area covered by bars. Only one relatively large island remained present along the reach in the 1970s: Ramier de Bigorre, distinctive for its inclusion in class 5 . In the 2000 s only two small islands and a few bars were present within the channel. We should also note that in this zone the channel migrated laterally until the 1970s, especially between 1868 and the 1940 s, before stabilizing at the end of the study period. 


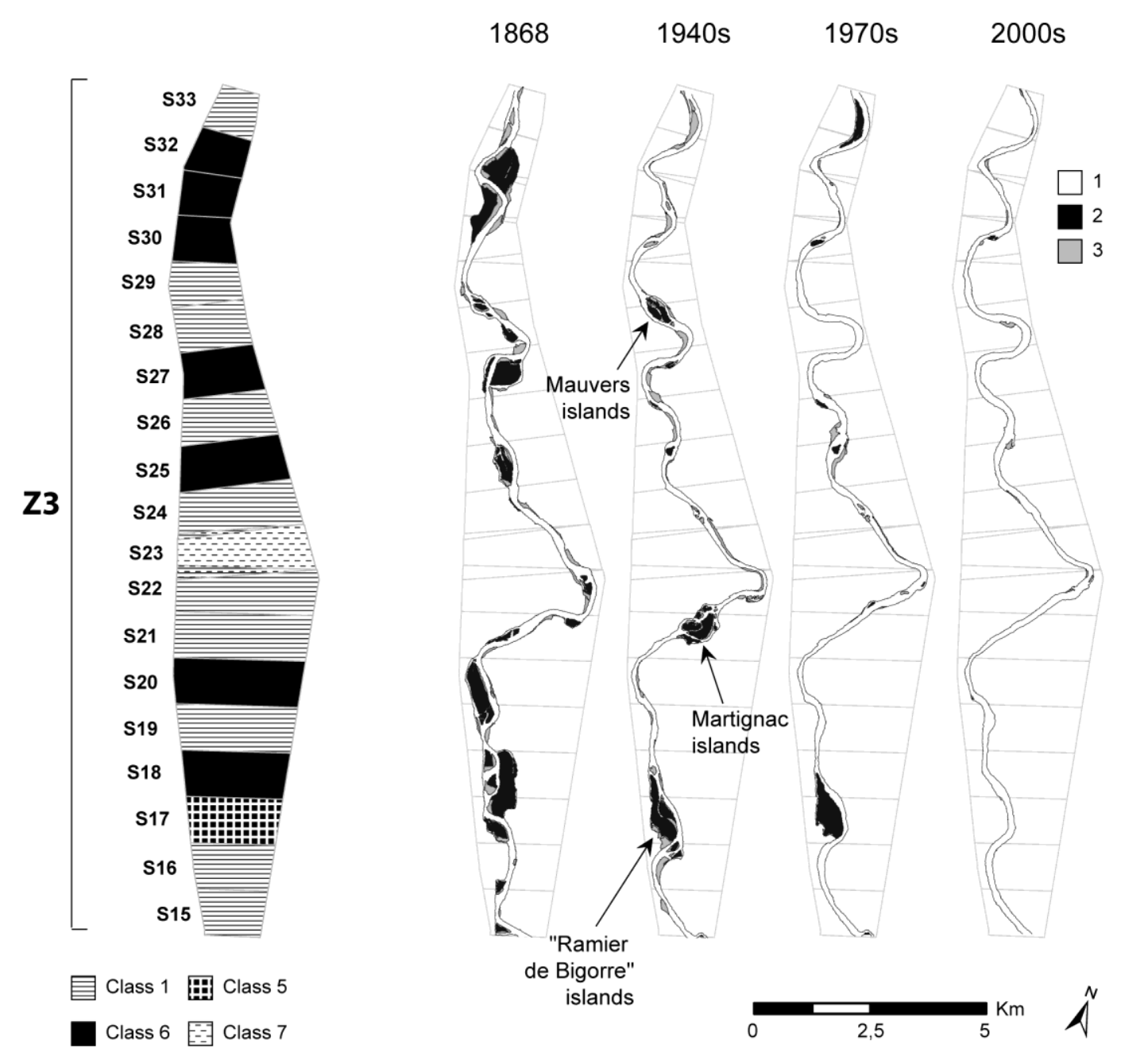

FIG12.TIF

Zone $4(\mathrm{Z4})(30 \mathrm{~km})$ presents greater heterogeneity than the others, as nearly all classes are represented (Fig. 13). This zone is nevertheless distinctive by the strong presence of classes 7 and 4 , which are respectively related to the presence of bars and the morphological simplicity of the channel throughout the study period. Indeed, only a few islands were found in this zone all through the study period, while numerous extensive point bars were apparent, especially in 1868 and the 1940s. We should note that the channel was sinuous and experienced rapid lateral mobility between 1868 and the 1970s, mainly in the sectors of class 7 , though it has been stable since then. The other classes included in zone 4 reveal several nuances within this general tendency. They especially emphasize sectors where islands had formed and disappeared at different dates over the study period (e.g., Monbecqui, Bourret, Saint-Cassian, Lizoun, and Castelmayran Islands). 


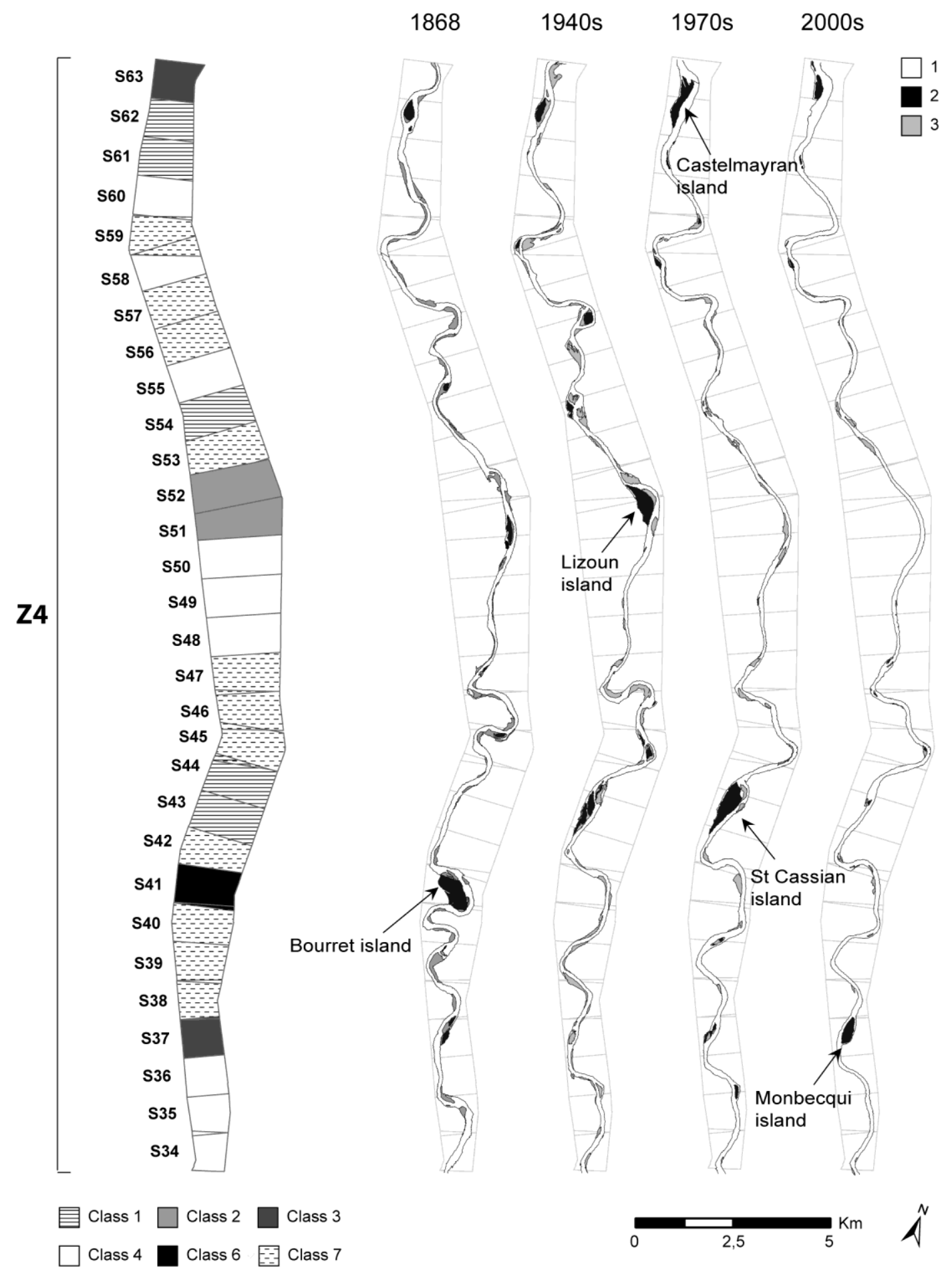

FIG13.TIF

\section{Discussion}

\subsection{Channel patterns}

In defining homogeneous zones by spatializing the typology of evolutionary trajectories, four 
distinct channel patterns are highlighted in the Toulouse middle Garonne over the 1868-2000s period. These patterns reflect varying behaviors of the channel along the study reach and through the study period. They can be described on the basis of three attributes (Fryirs and Brierley, 2013) measured at the zone scale at this stage of the analysis (Fig. 14): the degree of braiding (B), which is the ratio between the number of recorded secondary channels and the number of measurement points (i.e., transects) within each zone; sinuosity (SI), according to the method given above; and rate of channel migration (MI), which is the distance between two points, from one date to another, where the central axis of the channel is intersected by a transect. Thus, we distinguish: (i) a single-thread, sinuous, and laterally stable channel; (ii) a single-thread, sinuous channel evolving through slow lateral adjustments; (iii) a multithread, sinuous channel evolving through significant lateral adjustments; and (iv) a singlethread, sinuous channel evolving through significant lateral adjustments.

The single-thread, sinuous, and laterally stable channel is the dominant pattern in the upstream part of the study reach (Z1, $7 \mathrm{~km}$; Figs. 10, 14, and 15) throughout the 130-year study period. In this zone the channel is indeed weakly sinuous $(S \mathrm{SI} 1.2)$, with simple channel planforms (few islands and bars; $\mathrm{B}<0.5)$; no lateral adjustment was observed over the study period $\left(\mathrm{Ml}<2 \mathrm{~m}^{-1} \mathrm{y}^{-1}\right.$. By the end of the study period this channel pattern extended over the entire study reach.

The single-thread, sinuous channel evolving through slow lateral adjustments is observed in zone Z2 (7 km; Figs. 11, 14, and 15) at the beginning of the study period. Despite the relatively low

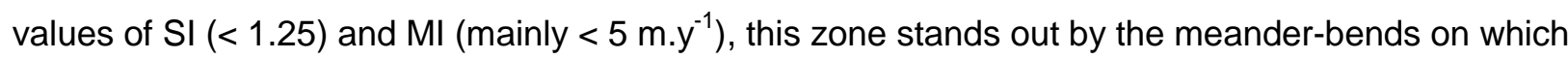
point bars were developed, reflecting a lateral migration/adjustment, likely slower than in downstream zones.

The multithread, sinuous channel evolving through significant lateral adjustments is found in the median zone (Z3, $19 \mathrm{~km}$; Figs. 12, 14, and 15), mainly in 1868. This part of the study reach included numerous islands at that date, highlighted by the degree of braiding $(B=0.8$, in 1868). We should note, however, that the channel was also highly sinuous $(1.3<\mathrm{SI}<1.4)$ and prone to lateral migration. Indeed, the channel included numerous point bars and MI reached $7 \mathrm{~m} \mathrm{yr}^{-1}$ between 1868 and the 1940s. 
The single-thread, sinuous channel evolving through significant lateral adjustments was observed mainly in the downstream zone (Z4, $30 \mathrm{~km}$; Figs. 13, 14 and 15) but also in the median zone (Z3) during the first half of the study period. In this zone the channel was highly sinuous $(1.3<\mathrm{SI}<1.4)$ and prone to lateral migration. Indeed, the channel included numerous point bars and MI exceeded 15 m. $y^{-1}$ at certain points of the reach. Additionally, the maps show varied meander-bend adjustments over the 1868-2000s period, such as extensions (Fig. 13 - S45; S59-60), translations (Fig. 13 - S35-36; S4142; S46; S57), and cutoffs (Fig. 13 - S40; S45; S46).

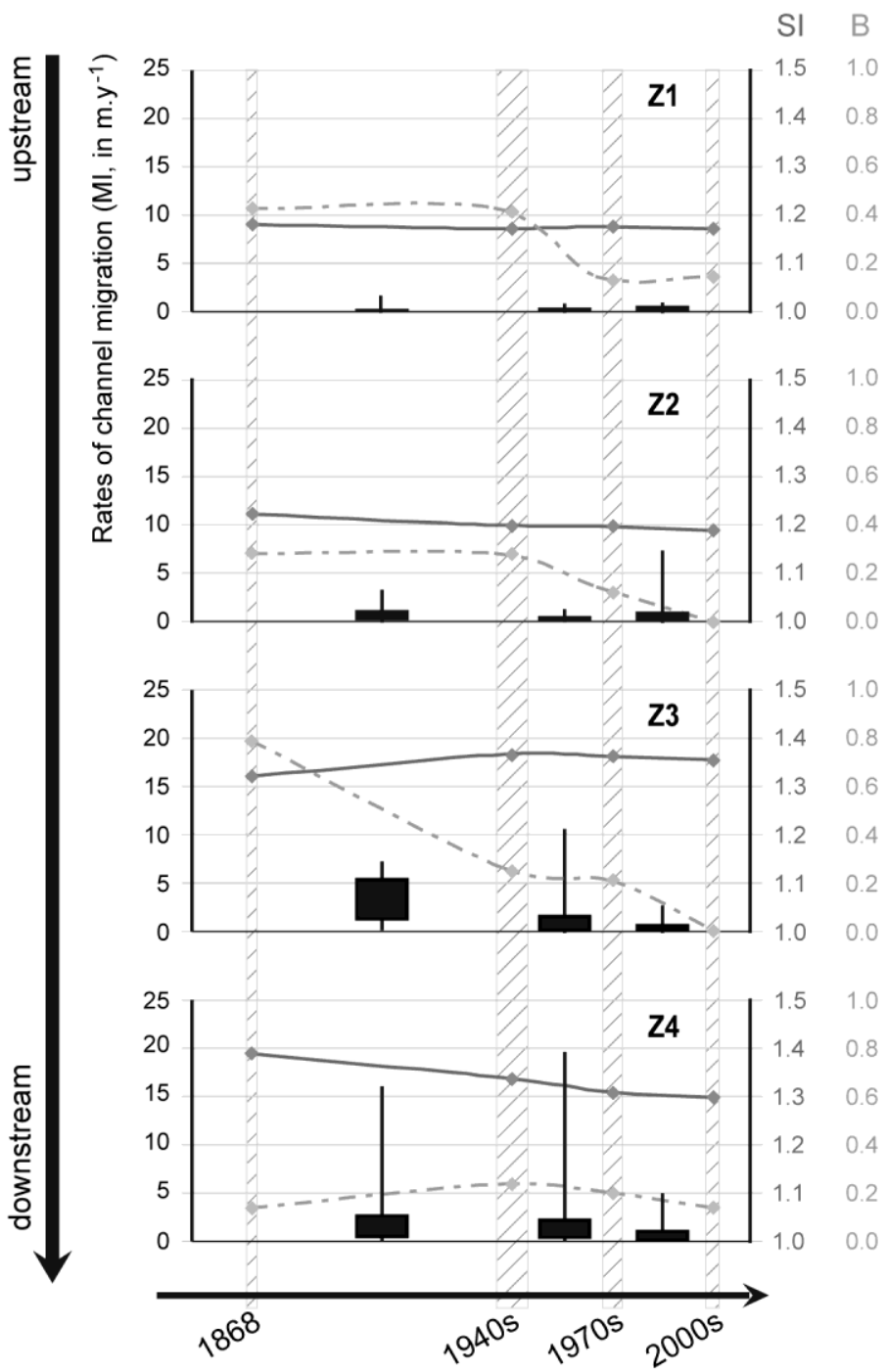

FIG14.TIF 


\subsection{Effect of zone position in the catchment and in the river reach}

River reach position in the catchment plays a significant role in controlling channel patterns. The Toulouse middle Garonne in the late nineteenth/early twentieth centuries is no exception to this rule. Indeed, the channel patterns defined above are consistent with those generally observed in the middle part of catchments of the same range. For example, they are consistent with those observed by Ollero (2010) on the middle Ebro River, which has equivalent slope, discharge, and valley settings (average slope: $0.67 \mathrm{~m} . \mathrm{km}^{-1}$; average discharge: $231 \mathrm{~m}^{3} . \mathrm{s}^{-1}$ in Castejon and $217 \mathrm{~m}^{3} . \mathrm{s}^{-1}$ in Zaragoza; average width of the floodplain: $3.2 \mathrm{~km}$ ). The channel of the middle Ebro before the $1950 \mathrm{~s}$ is described as meandering, divided into arms in several sectors, and including extensive sediment deposits. This channel evolved through meander-bend adjustments such as cutoffs.

In detail, the differences observed along the Toulouse middle Garonne are likely to be related to the valley floor, which is characterized by a widening in this part of the catchment related to the transition between the upper and middle Garonne. The upstream zones ( $Z 1$ and $Z 2)$ are indeed in a more confined valley than the median and downstream zones (Z3 and Z4), which limits the capacity for lateral adjustment (Brierley and Fryirs, 2005; Fryirs et al., 2009; Fryirs and Brierley, 2013). In these upstream zones, bedrock outcrops are (to date) larger than downstream (Steiger et al., 2000), which implies that more active vertical adjustments (i.e., incision) have occurred.

In the unconfined median-downstream part of the Toulouse middle Garonne (Z3 and Z4), the differences observed in channel patterns are likely to be linked to the confluence location and hence to local sediment inputs. Zone Z3 (Fig. 12), which was characterized by large islands in 1868, indeed includes the confluences of two tributaries, especially of the Hers River, which is the largest tributary of the Toulouse middle Garonne. A significant sediment load from the Hers may have been added to the Garonne by the end of the nineteenth century, leading to large alluvial deposits in zone Z3, which were then gradually colonized by vegetation. Additional field data highlighting the historical distribution of the sediment load in the catchment should be analyzed to further clarify this issue.

\subsection{Processes involved in channel change}


Throughout the 1868-2000s period, the different channel patterns became more homogeneous, evolving toward simpler and more stable planforms. Observation of the digitized historical maps revealed that the phenomenon took place through absorption of the channel' margins by the floodplain, the result of three distinct processes: (i) colonization by vegetation and removal of alluvial bars, (ii) erosion and attachment to the banks of vegetated islands, and (iii) decrease in lateral channel migration.

The digitized historical maps show the gradual disappearance of alluvial bars. This phenomenon, quantified in Fig. 6, occurred through two distinct processes: (i) colonization by vegetation of some central deposits, which is visible from one map to another (e.g., S11 in Z2, Fig. 11; S32-33 in Z3, Fig. 12); and (ii) disappearance of several lateral bars/point bars while a wetted channel widening occurred (Fig. 6; e.g., S38-39 in Z4, Fig. 13), reflecting the removal of alluvial deposits rather than an extension of vegetation. Sediment removal and colonization by vegetation are common phenomena in alluvial, sinuous rivers. However, in this case sediment outputs were not offset by new sediment inputs, reflecting a sediment mass balance deficit in the river reach/catchment.

A decrease in the area covered by vegetated islands was also observed, especially in zone Z3 between 1868 and the 1940s. Some islands eroded between these two periods, where a lateral migration of the channel occurred (e.g., the Martignac Island, Fig. 12). However, most islands became attached to the banks, following the disconnection of the secondary channels (e.g., S27; S31-32; S3233, Fig. 12). This phenomenon may reflect a decrease in sediment inputs from the tributaries, preventing the development of new alluvial deposits in the Garonne riverbed, and a channel incision, leading to the disconnection of the secondary channels. Once again, additional field data are necessary to further clarify this issue.

Channel stabilization, apparent on digitized historical maps, is well highlighted by lower rates of channel migration in zones Z3 and Z4 (Fig. 14). This phenomenon contributes to the fluvial area narrowing by leading to the disconnection of riparian margin areas. Moreover, the lack of lateral erosion likely contributes to the sediment mass balance deficit (Steiger et al., 1998). 


\subsection{Timing of channel change}

The timing of the channel changes described above (i.e., simplification, homogenization, and stabilization of channel patterns) differs upstream to downstream (Fig. 15). Channel behavior in the upstream-median zones (Z1, Z2, and Z3) evolved as of the beginning of the study period (i.e., between 1868 and the 1940s) through the attachment to the bank of an island and the removal of alluvial bars in zone Z1 (Fig. 10); the disappearance of alluvial bars and their colonization by vegetation in zone Z2 (Fig. 11); and in zone Z3, the attachment of the islands to the river banks (Fig. 12) or, more generally, the disappearance of the multithread channel pattern. The changes in the upstream-median zones are in agreement with the early phase of degradation observed in most European rivers, i.e., moderate channel narrowing and incision from the middle nineteenth/early twentieth centuries (Fig. 15).

The channel planforms in the downstream zone (Z4) did not record this evolution. Channel behavior in this zone evolved only over the second half of the twentieth century. The lateral adjustments decreased during this period. However, these recent changes are consistent with the secondary phase of degradation observed in the European rivers, characterized by an intensification of narrowing and incision (Fig. 15).

Our data set does not allow us to characterize the current tendency in the Toulouse middle Garonne. However, according to the sediment balance (few alluvial bars/large bedrock outcrops) and the lack of a global river restoration plan, we can be assume that no phase of recovery has occurred in this reach, in contrast with most Italian rivers. Thus, to date, the channel is likely controlled by vertical adjustments. 

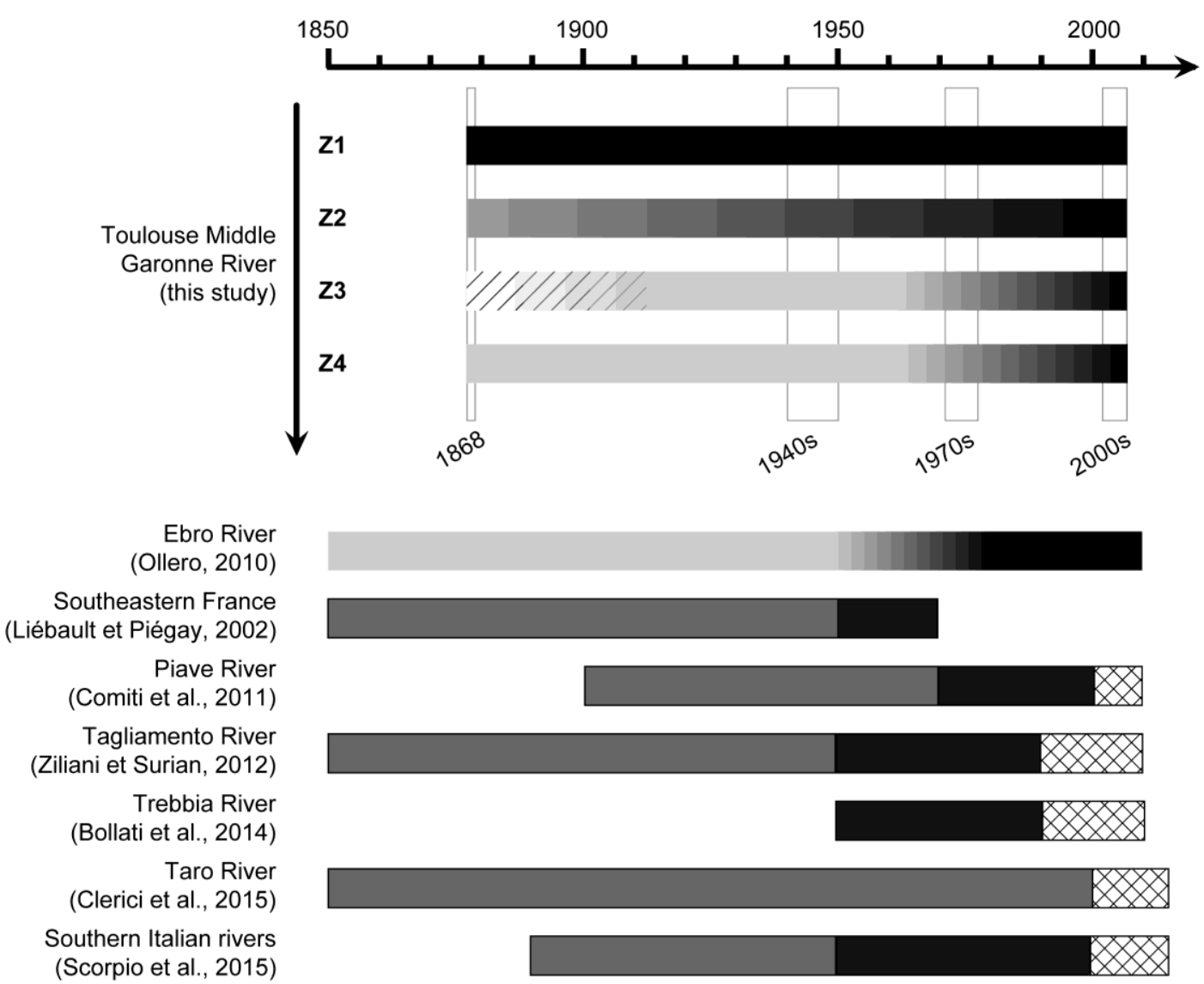

Garonne and Ebro rivers

single-thread, sinuous and laterally stable channel single-thread, sinuous channel, evolving through slow lateral adjutments

single-thread, sinuous channel, evolving through significant lateral adjutments

multi-thread, sinuous channel, evolving through significant lateral adjutments

\section{Southeastern France and Italian rivers}

Moderate channel narrowing, and incision in some cases

Significant channel narrowing and incision

$\$$ Widening/recovery phase, or stabilization in some cases

FIG15.TIF

\subsection{Controls on channel change}

The overall evolutionary trajectory of the Toulouse middle Garonne and the differences observed in its timing from upstream to downstream are likely the result of human impact on the river channel and on the catchment.

Indeed, the evolutionary trajectory of zone Z1 may be strongly dependent on the proximity of the city of Toulouse. In this zone, the end of the milling activity led to the disconnection of the mill tailraces, thus resulting in the attachment of Tounis Island to the bank as early as the beginning of the twentieth century (Fig. 10; Arrouy, 2005). This first control concerns only the zone near Toulouse as the 
channel's instability had always prevented the installation of land mills farther downstream (Valette, 2002). The later attachment to the banks of the other islands in zone $Z 1$ appears to be the result, following the flood of 1952, of the construction of earth dikes covered with concrete tiles, above and below the center of Toulouse (Fig. 2; Royer and Bonnelli, 2013).

The early disappearance of bars in zones Z1 and Z2 between 1868 and the 1940 s may be explained by more general controls. As of the beginning of the twentieth century, the first dams built in the Pyrenees (Fig. 2) limited the downstream alluvial load transfer by acting as sediment traps. Above all, in-stream gravel mining by local tradesmen, initially intended to facilitate navigation, became systematic during the nineteenth century and later expanded. These activities in the channel thus largely reduced alluvial deposits, especially immediately downstream from Toulouse (Beaudelin, 1989; Valette, 2002; Valette et al., 2014).

In addition to gravel mining, Valette (2002; Valette et al., 2014) has reported numerous individual works undertaken during the Modern era designed to reclaim land from the river and to concentrate water flow for navigation purposes. The construction of earth guards across secondary channels and the planting of willows to stabilize the banks may have contributed to the closing of secondary channels in zone Z3. However, the author points out that these types of structures were of marginal efficiency owing to their vulnerability to floods and thus are probably not the only factor involved in the disappearance of the multithread channel pattern in zone Z3.

Finally, in the downstream zone Z4, late stabilization of the channel coincides with the bank protection works undertaken between 1960 and 1984, confirming their role in channel change. For example, Lizoun Island, which appeared between 1868 and the 1940s through the colonization by vegetation of a point bar (Fig. 13), was intentionally attached to the banks in 1968. The effect of these works may have potentially been accentuated by bedrock incision induced by the growth of industrialized in-stream gravel mining in the riverbed between the 1960s and the end of the 1980s.

We can assume that a decrease in flood frequency and magnitude by the end of the nineteenth century, as shown in Fig. 2, played an additional role in channel change in having several effects on 
morphodynamics: depletion of upstream sedimentary sources, reduction of lateral erosion of watercourses, encouragement of colonization by vegetation of alluvial deposits, and increased efficacy of older riverside facilities designed to disconnect secondary channels. However, current knowledge concerning this topic is insufficient to clearly assess the share of climate control in the effects on the evolutionary trajectory of the Toulouse middle Garonne. Thus, this issue requires the implementation of further research.

\subsection{Implications for river management/restoration}

The results of this study can contribute to future river restoration projects in different ways. Four distinct evolutionary trajectories, controlled by various factors, have been highlighted, which may serve to identify varied reference states to be targeted within the Toulouse middle Garonne reach. Moreover, a gradient of inherent sensitivity to lateral adjustment (i.e., gradient of capacity for the river to adjust laterally; Brunsden and Thornes, 1979; Brunsden, 2001; Fryirs et al., 2009) has now been established along the Toulouse middle Garonne, showing a particularly stable zone in the upstream part of the reach and stronger rates of channel migration downstream. This gradient assumes that the upstream zones may be resilient to change (Brunsden and Thornes, 1979; Downs and Gregory, 1993) and thus resilient to restoration measures (Suding et al., 2004). Finally, the effects of the Hers River morphodynamics on historical channel planforms in the Toulouse middle Garonne imply that future restoration plans should be envisaged at the catchment scale.

\section{Conclusion}

The aim of this study was to propose a methodological essay for defining evolutionary trajectories of channel planforms within river reaches and to examine historical channel changes in the Toulouse middle Garonne (90 km between Toulouse and the Tarn River).

By using a set of four historical maps $(1868,1940$ s, 1970s, and 2000s) integrated within a GIS environment, this study provides a semi-automatic methodology for analyzing the evolutionary trajectory of channel planforms in the Toulouse middle Garonne. This approach can be summed up in 
five steps: (i) collection of geohistorical data; (ii) integration of geohistorical data within a GIS environment; (iii) segmentation of the floodplain into subreaches/sectors, using a semiautomatic method (Alber and Piégay, 2011) enriched here through standardization of the sectors; (iv) implementation of two geomorphometrical data sets by measuring $\sim 10$ parameters on each historical map, first at the sector scale and then at the reach scale; and (v) statistical analysis of data sets, especially the data set implemented at the sector scale, which was processed by using a mixed multiple factor analysis (MFAmix) and a hierarchical cluster analysis (HCA). Using MFAmix and HCA allowed an approach that is diachronic and multivariate and has given rise to an original result that is a typology of the evolutionary trajectories along the Toulouse middle Garonne. This method may be adapted to different types of fluvial systems by integrating new morphometric parameters, provided that accurate maps are available. However, a comparison between this multivariate diachronic method and a more classic approach (analysis of chart lines for each parameter) is necessary in order to clearly define the contributions and limits of each method in terms of working time and results. This perspective should be the subject of a new study.

The study has also shown and quantified overall simplification, homogenization, and stabilization of channel planforms in the Toulouse middle Garonne over the 130-year study period (i.e., reduction of sinuosity, decrease in the areas covered by vegetated islands and alluvial bars, homogenization of the shapes of islands and bars, and narrowing of the fluvial area). This study has shed light particularly on the fact that the timing of these changes varied from upstream to downstream. The channel planforms in the upstream and median zones were indeed simplified and homogenized very early in their history, as of the beginning of the study period between 1868 and the 1940s (i.e., colonization by vegetation of alluvial bars, attachment to the banks of islands, and narrowing of the fluvial area). This evolution occurred at the same time that the first phase of slight channel narrowing and incision was observed by numerous authors in European rivers generally. However, stabilization of the channel and the removal of alluvial bars in the downstream zone, which was initially a single-thread, sinuous channel evolving through lateral adjustments, began only after the 1940s. This change is consistent with the second phase of channel change previously observed in European rivers, which is characterized by increased processes of channel narrowing and incision. This new chronology situates the Garonne within the European timing of channel change and confirms the role of systematic 
protection bank works in the Tarn-et-Garonne section of the reach. This also reveals the morphogenic effect of human activities undertaken prior to the second half of the twentieth century (nonprofessional in-stream gravel mining, deliberate closing of secondary channels, and the first dams in the Pyrenees) and/or the shift from the LIA to GW (reduction in flood frequency and magnitude). Finally, these results may lend support to future restoration projects.

Despite the different contributions outlined above, the geohistorical data available does not allow a very high chronological resolution where the study reach is concerned. However, it does open possibilities for further study of zones or sites through an analysis much richer in number of dates now made available in plans for local improvements. In addition, the fact that the results of any study involving historical sources may not be totally certain is now widely recognized Thus, this study should be complemented by data from field work. Finally, research must now be extended to areas above and below the middle Garonne so as to establish better connections between the evolutions observed and especially the question of upstream-downstream gradients/connectivity that remain unclear at the scale under consideration.

\section{Acknowledgements}

This research, based on the Ph.D thesis of the lead author, is part of a larger study on the evolutionary trajectory of morphodynamics of the Garonne River over the Anthopocene era. This research, undertaken as a part of the ANR ADAPT'EAU project (ANR-11-CEPL-008), benefited from financial aid from the Agence Nationale de la Recherche (ANR) under the program Changements Environnementaux Planétaires and Sociétés (CEP\&S). It also benefited from financial aid from the Aquitaine and Midi-Pyrenees Regions as a part of the GAGILAU (GAronne Glronde Saint-LAUrent) program. The authors thank the anonymous reviewers for their constructive comments and suggestions, and $\mathrm{M}^{\mathrm{r}}$. John Olsen for his translation from French.

\section{References}

Alber, A., Piégay, H., 2011. Spatial disaggregation and aggregation procedures for characterizing fluvial 
features at the network-scale: Application to the Rhône basin (France). Geomorphology 125, 343-360.

Arnaud, F., 2012. Approches géomorphologiques historique et expérimentale pour la restauration de la dynamique sédimentaire d'un tronçon fluvial aménagé: le cas du Vieux Rhin entre Kembs et Breisach (France, Allemagne). Ph.D. Thesis, University of Lyon, France.

Arnaud, F., Piégay, H., Schmitt, L., Rollet, A.J., Ferrier, V., Béal, D., 2015. Historical geomorphic analysis (1932-2011) of a by-passed river reach in process-based restoration perspectives: The Old Rhine downstream of the Kembs diversion dam (France, Germany). Geomorphology 236, 163-177. Arnaud-Fassetta, G., 2003. River channel changes in the Rhone Delta (France) since the end of the Little Ice Age: geomorphological adjustment to hydroclimatic change and natural resource management. Catena 51, 141-172.

Arrouy, J.-M., 2005. L'île de Tounis. Loubatières, Portet-sur-Garonne, France.

Astrade, L., Jacob-Rousseau, N., Bravard, J.-P., Allignol, F., Simac, L., 2011. Detailed chronology of mid-altitude fluvial system response to changing climate and societies at the end of the Little Ice Age (Southwestern Alps and Cévennes, France). Geomophology 133, 100-116.

Beaudelin, P., 1989. Conséquences de l'exploitation des granulats dans la Garonne. Revue Géographique des Pyrénées and du Sud-Ouest 60 4, 603-616.

Bensizerara, D., Chenchouni, H., Si Bachir, A., Houhamdi, M., 2013. Ecological status interactions for assessing bird diversity in relation to a heterogeneous landscape structure. Avian biology research 6, 1 , 67-77.

Bollati, I.M, Pellegrini, L., Rinaldi, M., Duci, G., Pelfini, M., 2014. Reach-scale morphological adjustments and stages of channel evolution: The case of the Trebbia River (northern Italy).

Bravard J.P., Amoros, C., Pautou, G., Bornette, G., Bournaud, M., Creuzé des Châteliers, M., Gibert, J., Peiry, J.L., Perrin, J.F., Tachet, H., 1997. River incision in south-east France: morphological phenomena and ecological effects. Regul. River. 13, 75-90.

Brierley G.J., Fryirs, K., 2005. Geomorphology and River Management: Applications of the River Styles Framework. Blackwell Publishing, Oxford, 398 pp.

Brierley, G.J., Fryirs, K.A., Boulton, A., Cullum, C., 2008. Working with change: the importance of evolutionary perspectives in framing the trajectory of river adjustment. In: Brierley, G., Fryirs, K.A. (Eds.), River Futures: An Integrative Scientific Approach to River Repair. Society for Ecological Restoration International, Island Press, Washington, DC, USA, pp. 65-84. 
Brookes, A., 1988. Channelized Rivers: Perspectives for Environmental Management. J. Wiley and Sons, Chichester, U.K..

Brunsden, D., 2001. A critical assessment of the sensitivity concept in geomorphology. Catena 42, 99123.

Brunsden, D., Thornes, J.B., 1979. Landscape sensitivity and change. Transactions of the Institute of British Geographers NS4. 463-484.

Campana, D., Marchese, E., Theule, J.I., Comiti, F., 2014. Channel degradation and restoration of an Alpine river and related morphological changes. Geomorphology 221, 230-241.

Carozza, J.-M., Puig, C., Odiot, T., Valette, P., Passarrius, O., 2012. Lower Mediterranean plain accelerated evolution during the Little Ice Age: Geoarchaeological insight in the Tech basin (Roussillon, Gulf of Lion, Western Mediterranean). Quaternary International 266, 94-104.

Chavent, M, Kuentz-Simonet, V, Saracco, J, 2012. Orthogonal rotation in PCAMIX. Advances in Data Analysis and Classication 6, 131-146.

Clément, P., Piégay, H., 2003. Statistics and Fluvial Geomorphology. In: Kondolf, M.G., Piégay, H. (Eds), Tools in fluvial geomorphology. J. Wiley and Sons, Chichester, U.K., pp. 597-630.

Clerici, A., Perego, S., Chelli, A., Tellini, C., 2015, Morphological changes of the floodplain reach of the Taro River (Northern Italy) in the last two centuries. Journal of Hydrology 527, 1106-1122.

Comiti, F., Da Canal, M., Surian, N., Mao, L., Picco, L., Lenzi, M.A., 2011. Channel adjustments and vegetation cover dynamics in a large gravel bed river over the last 200 years. Geomorphology 125 , 147-159.

David, M., Carozza, J.-M., Valette, P., Llubes, M., Py, V., Groparu, T., 2015. The fluvial dynamics of the middle Garonne river documented by combining historical maps, stratigraphy and geophysics approaches on the Grenade-Ondes study site. Géomorphologie: relief, processus, environnement 211 , 21-44.

Decamps, H., Fortuné, M., Gazelle, F., 1989. Historical Changes of the Garonne River, Southern France. In: Petts G.-E. (Ed.), Historical Change of Large Alluvial Rivers: Western Europe. J. WileySons, Chichester, U.K., pp. 249-267.

Deffontaines, P., 1932. Les hommes and leurs travaux dans les pays de la moyenne Garonne (Agenais, Bas-Quercy). P.h.D. Thesis, University of Lille, France.

Delmouly, L., Moreau, N., Croze, O., Le Barh, R., 2007. Cartographie du substrat de la Garonne (de la 
retenue de St-Nicolas-de-la-Grave à Toulouse) et influence sur le comportement de saumons atlantiques en remontée. Agence de l'eau Adour Garonne, technical report.

Direction Départementale du Tarn et Garonne (DDE 81), 2006. Etude de la dynamique fluviale de la Garonne en amont du plan d'eau de St Nicolas de la Grave. Technical report, 67 p.

Downs, P.W., Gregory, K.J., 1993. The sensitivity of river channels in the landscape system. In:

Thomas, D.S.G., Allison, R.J. (Eds), Landscape Sensitivity. John Wiley \& Sons, Chichester, 15-30.

Escofier, B., Pagès, J., 1994. Multiple factor analysis (AFMULT package). Comput. Stat. and Data Anal. $18,121-140$.

Escofier, B,. Pagès, J., 1998. Analyses factorielles simples et multiples. 3e ed. Dunod, Paris, France.

Erskine, W.D., 1992. Channel response to large scale river training works: Hunter river, Australia, Regul River 7, 261-268.

Fryirs, K.a., Brierley, G., 2013. Geomorphic analysis of river systems: an approach to reading the landscape. John Wiley \& Sons, Chichester, 360 p.

Fryirs, K., Spink, A., Brierley, G., 2009. Post-European settlement response gradients of river sensitivity and recovery across the upper Hunter catchment, Australia. Earth Surf. Proc. Land. 34, 897-918.

Geoportail. Geographic database of the French Ministry of Ecology, Sustainable Development and Energy. Last connection November 17, 2015. URL: http://www.geoportail.gouv.fr/accueil

Gob, F., Jacob, N., Bravard, J.P., Petit, F., 2008. The value of lichenometry and historical archives in assessing the incision of submediterranean rivers from the Little Ice Age in the Ardèche and upper Loire (France). Geomorphology 94, 170-183.

Goudie, A.S., 2013. The human impact on the natural environment, past, present and future. J. Wiley and Sons, Chichester, U.K..

Gregory, K.J., 2006. The human role in changing river channels. Geomorphology 79 3-4, 172-191. Gurnell, A.M., 1997. Channel change on the river Dee meanders, 1946-1992, from the analysis of air photographs. Regul River 22, 967-985.

Gurnell, A.M., Peiry, J.L., Petts, G., 2003. Using historical data in fluvial geomorphology. In: Kondolf, M.G., Piégay, H. (Eds), Tools in fluvial geomorphology. J. Wiley and Sons, Chichester, U.K., pp. 77-101. Harlé, E., 1895. Observations sur les alluvions de la Garonne dans la région de Toulouse. Bull. Soc. Géol. Fr. 23, 490-503.

Hickin, E.J., Nanson, G.C., 1984. Lateral migration rates of river bends. J. Hydraul. 110, 1557-1567. 
HYDRO. Hydrological database of the French Ministry of Ecology, Sustainable Development and Energy. Last connection November 17, 2015. URL:

http://www.hydro.eaufrance.fr/selection.php?consulte=rechercher

Info Terre - Database of the French geological and mining research office (BRGM - Bureau de Recherche Biologique et Minière). Last connection November 17, 2015. URL:

http://infoterre.brgm.fr/viewer/MainTileForward.do;jsessionid=B38C18332877C45C1038FBD5B6BB050 5

James, M., 1996. Le dépérissement des boisements riverains de la Garonne: évaluation à partir de données de structure forestière et de télédétection à haute résolution spatiale. Ph.D. Thesis, University of Toulouse, France.

Kiss, T., Blanka, V., 2012. River channel response to climate and human induced hydrological changes: Case study on the meandering Hernád River, Hungary. Geomophology 175-176, 115-125.

Kondolf, G.M., 1997. Hungry water: effects of dams and gravel mining on river channels. Environmental Management 21, 533-551.

Kondolf G.M., Larson, M., 1995. Historical channel analysisits application to riparian and aquatic habitat restoration. Aquatic Conservation: Marine and Freshwater Ecosystems 5, 109-126.

Lambert, R., 1989. La moyenne Garonne aval: géomorphologie et dynamique des crues, Revue Géographique des Pyrénées and du Sud-Ouest 60 4, 555-567.

Latapie, A., Camenen, B., Rodrigues, S., Paquier, A., Bouchard, J.P., Moatar, F., 2014. Assessing channel response of a long river influenced by human disturbance. Catena 121, 1-12.

Lewin, J., 1987. Historical river channel changes. In Gregory, K.J., Lewin, J., Thornes, J.B., eds., Paleohydrology in practice. Chichester, Wiley, pp. 161-175.

Liébault, F., Piégay, H., 2002. Causes of twentieth century channel narrowing in mountain and piedmont rivers of southeastern France. Earth Surf. Proc. Land. 27, 425-444.

Mamoudou, M., 2008. Dynamique de transfert des matières organiques and inorganiques le long du continuum fluvial de la Garonne: impact de la retenue de Malause. Ph.D. Thesis, National Polytechnical Institute of Toulouse, France.

Marston, R.A., Girel, J., Pautou, G., Piégay, H., Bravard, J.P., Arneson, C., 1995. Channel metamorphosis, floodplain disturbance, and vegetation devlopment: Ain River, France. Geomorphology $13,121-131$. 
Mergoil, G., 1993. Farouche ou aimable Garonne. In: Bernad, C. (Ed.), La Garonne. Privat, Toulouse, France.

Millennium Ecosystem Assessment (MEA), 2005. Ecosystems and Human Well-Being: wetlands and water. Island Press, Washington, DC, USA, $68 \mathrm{pp}$.

Muller, E., Guilloy-Froget, H., Barsoum, N., Brocheton, L., 2002. Populus nigra L. en vallée de Garonne: legs du passé and contraintes du présent. C. R. Biologies 325, 1129-1141.

Nicoll, T.J., Hickin, E.J., 2010. Planform geometry and channel migration of confined meandering rivers on the Canadian prairies. Geomorphology 116, 37-47.

Ollero, A., 2010. Channel changes and floodplain management in the meandering middle Ebro River, Spain. Geomorphology 117, 247-260.

Pardé, M., 1928. Périodicité des grandes inondations et crues exceptionnelles. Revue de géographie alpine 162 , 499-519.

Patrick, D.M., Smith, L.M., Whitten, C.M., 1982. Methods for studying accelerating fluvial change. In Hey, R.D., Bathurst, J.C., Thorne, C.E., eds., Gravel bed rivers. Chichester, Wiley, pp. 783-815. Payraudeau, S., Galliot, N., Lliébault, F., Auzet, A.V., 2010. Incertitudes associées aux données géographiques pour la quantification des vitesses de migration des méandres. Application à la basse vallée de la Bruche. Revue internationale de géomatique 20/2, 221-243.

Peiry, J.L., Nouguier, F., 1994. Le Drac dans l'agglomération de Grenoble: première évaluation des changements géomorphologiques contemporains. Revue de géographie alpine tome $82, n^{\circ 2}$, 77$\underline{96 .}$

Petts, Muller, Roux, 1989. Historical change of large alluvial rivers: Western Europe. Chichester, Wiley. Provansal, M., Dufour, S., Sabatier, F., Anthony, E.J., Raccasi, G., Robresco, S., 2014. The geomorphic evolution and sediment balance of the lower Rhône River (southern France) over the last 130 years: Hydropower dams versus other control factors. Geomophology 219, 27-41.

Puech, C., Baudry, J., Joannon, A., Poggi, S., Aviron, S., 2014. Organic vs. conventional farming dichotomy: Does it make sense for natural enemies? Agr. Ecosyst. environ. 194, 48-57.

Radoane, M., Obreja, F., Cristea, I., Mihaila, D., 2013. Changes in the channel-bed level of the eastern Carpathian rivers: Climatic vs. human control over the last 50 years. Geomorphology 193, 91-111. Rinaldi, M., Simoncini, C., Piégay, H., 2009. Scientific design strategy for promoting sustainable sediment management: the case of the Magra river (Central-Northern Italy). River Res. Appl. 25, 607- 
625.

Royer, P., Bonnelli, S., 2013. Digues maritimes and fluviales de protection contre les submersions. $2^{\mathrm{e}}$ Colloque national Digues2013, conference report, Aix-en-Provence, 12-14 juin 2013.

Rumsby, B.T., Macklin, M.G., 1996. European river response to climate changes over the last neoglacial cycle (the 'Little Ice Age'). In: Branson, J., Brown, A.G., Gregory, K.J. (Eds.), Global Continental Changes: The Context of Palaeohydrology. Geological Society Special Publication, 115. Geological Society, London, pp. 217-233.

Scorpio, V., Aucelli, P.P.C., Giano, S.I., Pisano, L., Robustelli, G., Rosskopf, C.M., Schiattarella, M., 2015. River channel adjustments in Southern Italy over past 150 years and implications for channel recovery. Geomorphology, in press.

Segura-Belträn, F., Sanchis-lbor, C., 2013. Assessment of channel changes in a Mediterranean ephemeral stream since the early twentieth century. The Rambla de Cervera, eastern Spain. Toone and al., 2014

Steiger, J., Corenblit, D., 2000. Dynamique fluviale de la Garonne toulousaine. Agence de l'eau AdourGaronne, technical report.

Steiger, J., James, M., Gazelle, F., 1998. Channelization and consequences on floodplain system functioning on the Garonne river, SW France. Regul. River 14, 13-23.

Steiger, J., Corenblit, D., Vervier, p., 2000. Les ajustements morphologiques contemporains du lit mineur de la Garonne (France) and leurs effets sur l'hydrosystème fluvial. Z. Geomorphol. 122, 227246.

Suding, K.N., Gross, K.L., Houseman, G.R., 2004. Alternative states and positive feedbacks in restoration ecology. Trend. Ecol. Evol. 19, 1, 46-53.

Surian, N., Cisotto, A., 2007. Channel adjustments, bedload transport and sediment sources in a gravel-bed river, Brenta River, Italy. Earth Surf. Process. Landf. 32, 1641-1656.

Surian, N., Rinaldi,M., 2004. Channel adjustments in response to human alteration of sediment fluxes: examples from Italian rivers. In: Golosov, V., Belyaev, V., Walling, D.E. (Eds.), Sediment Transfer through the Fluvial System, Proc. Symposium and Moscow, August 2004. IAHS Publ., 288, pp. 276282.

Surian, N., Rinaldi, M., Pellegrini, L., Audisio, C., Maraga, F., Teruggi, L., Turitto, O., Ziliani, L., 2009. Channel adjustments in northern and central Italy over the last 200 years. In: James, L.A., Rathburn, 
S.L., Whittecar, G.R. (Eds.), Management and Restoration of Fluvial Systems with Broad Historical Changes and Human Impacts: Geological Society of America Special Paper 451, pp. 83-95.

Toone, J., Rice, S.P., Piégay, H., 2014. Spatial discontinuity and temporal evolution of channel morphology along a mixed bedrock-alluvial river, upper Drôme River, southeast France: Contingent responses to external and internal controls. Geomorphology 205, 5-16.

Uribelarrea, D., Pérez-Gonzalez, A., Benito, G., 2003. Channel changes in the Jarama and Tagus rivers (central Spain) over the past 500 years. Quaternary sci. rev. 22 20, 2209-2221.

Valette, P., 2002. Les paysages de la Garonne: les métamorphoses d'un fleuve (entre Toulouse and Castet- en-Dorthe). Ph.D. Thesis, University of Toulouse, France.

Valette, P., 2004. Les cartes et plans de la moyenne Garonne de l'époque moderne à nos jours. CFC 182, 41-50.

Valette, P., Carozza, J.-M., 2010. Mise en œuvre d'une démarche géohistorique pour la connaissance de l'évolution des paysages fluviaux: l'exemple de la moyenne vallée de la Garonne. Géocarrefour 85 $1,17-27$

Valette, P., Gazelle, F., 2000. L'impact des sociétés du XVIII et du XIX ${ }^{e}$ s. sur les paysages garonnais. Géocarrefour 75 4, 337-345.

Valette, P., Carozza, J.-M., Salles, D., David, M., Simonet, G., 2014. Construction géohistorique du "sauvage" de la Garonne toulousaine: quelle part de naturalité dans les paysages fluviaux?

Développement durable \& territoires 53.

Wellmeyer, J.L., Slattery, M.C., Phillips, J.D., 2005. Quantifying downstream impacts of impoundment on flow regime and channel planform, lower Trinity River, Texas. Geomorphology 69, 1-4, 1-13.

Winterbottom, S.J., 2000. Medium and short-term channel planform changes on the Rivers Tay and Tummel, Scotland. Geomorphology 34, 3-4, 195-208.

Zawiejska, J., Wyzga, B., 2010, Twentieth-century channel change on the Dunajec River, southern Poland: Patterns, causes and controls. Geomorphology 117, 234-246.

Ziliani, L., Surian, N., 2012. Evolutionary trajectory of channel morphology and controlling factors in a large gravel-bed river. Geomorphology 173-174, 104-117. 


\section{Figure captions}

Fig. 1. Location map of the Garonne catchment (southwestern France), showing the study reach within the middle Garonne River.

1 hydrogeomorphological typology of the Garonne; 2 departmental boundary between the HauteGaronne (south) and the Tarn-et-Garonne (north); 3 main rivers; 4 towns cited in the text; 5 gauging stations (1: Toulouse-Portet, 2: Verdun-sur-Garonne, 3: Saint-Aignan, 4: Lamagistère); 6 Digital Elevation Model (DEM) at $25 \mathrm{~m}$ resolution provided by IGN (elevation in $\mathrm{m}$ above sea level).

Fig. 2. Climatic and anthropogenic events that occurred during the $1850-2000$ period and that probably affected the middle Garonne dynamics.

(A) Daily discharge $\left(\mathrm{m}^{3} . \mathrm{s}^{-1}\right)$ recorded at the Toulouse-Portet gauging station since 1910 (HYDRO data set). (B) Water level $(\mathrm{m})$ recorded since 1850 near the bridge named 'Pont neuf' at Toulouse (HYDRO data set). (C) Main dams (cumulative number) built in the Pyrenees (French Committee of the Dams and Reservoirs - 'Comité Français des Barrages and Réservoirs'). (D) Gravel mining in the channel of the middle Garonne between Toulouse and the departmental boundary of the Lot-et-Garonne ( 100 km in length) from 1965 to 1985 (Beaudelin, 1989). (E) Length of protected banks (km), i.e., the dikes built from 1950 to 1957 upstream and downstream from Toulouse, and the rip rap made in the Tarn-etGaronne section between 1960 and 1984 (Prevention Plan for Flood Risk of Toulouse - 'Plan de Prévention du risque inondation'; and Valette, 2002).

Fig. 3. Schematization of the methodological framework.

Fig. 4: Cover, date, and scale of the maps in use for the 1940 s and the 1970 s.

Fig. 5. Calculation of geomorphometrical parameters.

(A) Definition of digitized fluvial planforms: the historical maps' captions are reported for each fluvial planform. (B) Method for floodplain segmentation: 1 historical meander-belt (HMB) encompassing the channel at the four periods (1868, 1940s, 1970s, and 2000s); 2 central axis of the HMB; 3 'sectors' 1 $\mathrm{km}$ in length, perpendicular to the HMB central axis and geometrically identical; 4 areas where sectors 
are superimposed; 5 transects traced in the center of each sector perpendicular to the HMB central axis to enable any one-time measurements. (C) Schematization of the 10 geomorphometrical parameters: MCW is main channel width; SCW is secondary channels width; $\mathrm{C}$ axis is the central axis of the channel; and SL is the straight line between the two end points of the reach.

Fig. 6. Univariate descriptive analysis at the reach level (63 $\mathrm{km}$ in length).

Sinuosity (SI), vegetated area (VA), and nonvegetated area (NVA) are raw values. The widths of the fluvial area (FAW) and wetted channel (WCW) are average values. The presence of secondary channels (SC) is a percentage of sectors with positive values. The size (S), perimeter (P), Gravelius $(G)$, and nearest distance to a bank (ND) are shown with box plots: the vertical line defines the range between the maximum and minimum values; the box shows the first quartile (Q1: $25 \%$ of the values is below the median) and the third quartile (Q3: $25 \%$ of the values is above the median), and the dot shows the average value. The closer to 0 the value of the Gravelius index $(G)$, the more circular the form; the farther $\mathrm{G}$ is from 0 , the more elongated the form. The tables report rates of change during the study period.

Fig. 7. Results of the mixed multiple factor analysis (MFAmix).

The correlation circles (up) report the position on the four axes of each of the eight quantitative parameters measured at each date. The modality maps (down) report the position on the four axes of the only qualitative parameter measured at each date, except for the 1940s, which was excluded from the analysis. $\mathrm{SC}=1$ is presence of secondary channel; $\mathrm{SC}=0$ is absence of secondary channel.

Fig. 8. Results of the hierarchical cluster analysis (HCA).

(A) Dendrogram ordering the 63 sectors into seven hierarchical clusters. (B) Test values for each cluster.

Fig. 9. Cartography of the HCA results and segmentation of the entire reach into homogeneous zones. Classes 1 to 7 correspond to the HCA clusters: class 1 corresponds to small and circular islands at the beginning of the study period, which were situated far from the banks; class 2 corresponds to the sectors covering large vegetated islands in the 1940s; class 3 corresponds to large vegetated islands in 
the 2000s; class 4 corresponds to the parts of the study reach marked by a certain morphological simplicity throughout the study period; class 5 corresponds to one or more large vegetated island(s) in the 1940s and 1970s; class 6 corresponds to large vegetated islands in 1868; and class 7 corresponds to the sectors marked by the presence of bars throughout the study period. Zones $Z 1$ to $Z 4$ show a segmentation of the entire reach into four homogeneous zones, each one characterized by the presence/dominance of one or several HCA classes.

Fig. 10. Evolutionary trajectory of Zone 1 (Z1).

Classes 1 to 3 correspond to the HCA clusters.

1 channel, 2 islands, and 3 bars.

Fig. 11. Evolutionary trajectory of Zone 2 (Z2).

Classes 1 and 4 correspond to the HCA clusters.

1 channel, 2 islands, and 3 bars.

Fig. 12. Evolutionary trajectory of Zone 3 (Z3).

Classes 1, 5, 6 and 7 correspond to the HCA clusters.

1 channel, 2 islands, and 3 bars.

Fig. 13. Evolutionary trajectory of Zone 4 (Z4).

Classes 1 to 7 correspond to the HCA clusters.

1 channel, 2 islands, and 3 bars.

Fig. 14. Attributes describing the behavior of the channel at the zone scale.

The interdate rate of channel migration $(\mathrm{MI})$ is shown with box plots: the vertical line defines the range between the maximum and minimum values; the box shows the first quartile (Q1: $25 \%$ of the values is bellow the median) and the third quartile (Q3: $25 \%$ of the values is above the median). The evolution of sinuosity $(\mathrm{SI})$ is shown with dark grey lines, and the evolution of the degree of braiding $(\mathrm{B})$ is shown with light grey lines. 
Fig. 15. Chronology of channel change in the Toulouse middle Garonne and some other European rivers.

The evolutionary trajectory of the channel patterns of the Toulouse middle Garonne are shown at the zone scale. A comparison with the major phases of adjustments observed in most European rivers is then proposed.

\section{Table 1}

Hydrological, geomorphological, and sediment settings. $A_{\mathrm{d}}$ : drainage area, $Q_{\mathrm{m}}$ : mean annual discharge, $Q_{\min }$ : minimal monthly discharge on a water year (average values), $Q_{5}-Q_{20}-Q_{50}$ : discharge that is exceeded 5, 20 and $50 \%$ of the time, $Q_{100}$ : peak discharge estimated for the flood of 23 June 1875, $L$ : channel length between the confluence of the Ariège River and the confluence of the Tarn River, Sl: sinuosity, $W_{\mathrm{m}}$ : mean channel width, $Z_{\mathrm{m}}$ : mean channel depth, $S_{\mathrm{m}}$ : mean channel slope, $\omega$ : specific stream power, $S L C_{\mathrm{m}}$ : suspended load concentration, measured from sediment samples taken at 17 stations.

\section{Table 2}

Information on the way in which historical data are georeferenced. Division: the initial image was subdivided before georeferencing; $x$ and $y$ : the $x$ and $y$ coordinates were assigned using the initial projection, and the map was then reprojected using Lambert 93; base map: the map was georeferenced onto a base map (SCAN $25 \AA$ ) by selecting GCPs on the map to be warped and on the SCAN 25®; GCPs: ground control points; RMS error: root mean square error. 


\section{Highlights}

- We propose a methodology for defining evolutionary trajectories of fluvial dynamics

- We quantify the evolution of the middle Garonne River over the 150 years

- We propose a segmentation of the study reach into four homogeneous zones

- We confirm the role of systematic improvements made between 1960 and 1984

- We reveal the morphogenic effect of controlling factors prior to the 1950s 